
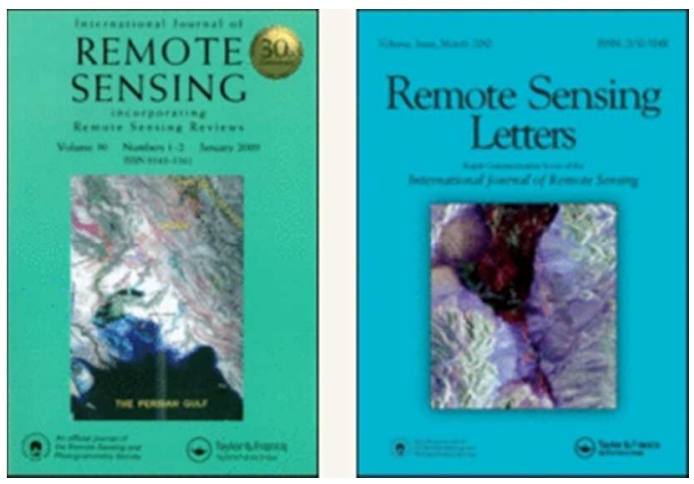

\title{
Ground-based hyperspectral imaging as a tool to identify different carbonate phases in natural cliffs
}

\begin{tabular}{|r|l|}
\hline Journal: & International Journal of Remote Sensing \\
\hline Manuscript ID & TRES-PAP-2017-0433.R1 \\
\hline Date Submitted by the Author: & 12-Oct-2017 \\
\hline Complete List of Authors: & $\begin{array}{l}\text { Beckert, Julia; Imperial College London } \\
\text { Vandeginste, Veerle; Imperial College London } \\
\text { McKean, Tilden; Statoil ASA } \\
\text { Alroichdi, Amer; Mapping Solutions Ltd. } \\
\text { John, Cedric; Imperial College London }\end{array}$ \\
\hline Keywords: & $\begin{array}{l}\text { hyperspectral data, near-infrared, Principal components analysis (PCA), } \\
\text { semi-arid land }\end{array}$ \\
\hline Keywords (user defined): & \\
\hline & \\
\hline
\end{tabular}

SCHOLARONE ${ }^{\text {m }}$

Manuscripts 


\section{Abstract}

Recent research has shown hyperspectral imaging to be a powerful tool to distinguish carbonate phases with slight compositional differences on quarry cliff faces. The traditional remote sensing set-up uses an optimal short distance between the hyperspectral camera mounted on a tripod and a quarry wall characterized by a planar, mostly unweathered surface. Here we present results of a modified workflow geared to the application of ground-based hyperspectral imaging of rough and weathered cliff faces in order to map large scale dolomite bodies from a distance of up to several kilometres. The goal of the study was to determine unique spectral properties of fracture-controlled dolomite bodies in order to be able to distinguish them from a dolomitic host rock. In addition, the impact of weathering on carbonate phases and thus, the modification of the spectral signature between altered and unaltered carbonates is assessed. The spectral analysis is complemented by ICP-AES measurements of the spectrally measured powders. Furthermore, we examined the detection limits and characterisation potential of dolomite bodies from hyperspectral images captured at varying distances from cliff faces in the study area. Hyperspectral images of 10 natural cliffs distributed across the Central Oman Mountains were obtained with a Push broom scanner system. The high resolution of $5.45 \mathrm{~nm}$ (288 bands in total) enabled the visualization of small-scale changes in the near infrared continuous spectrum of all present lithofacies types.

The determination of dolomite bodies of varying sizes (metre to hundreds of metres) on natural cliffs was achieved with the hyperspectral mapping approach and mapping results have been tested with the position of visually defined dolomite bodies on field panoramas. Spectra of natural cliffs contain a strong absorption peak indicative for iron which is absent in spectra of unweathered sample powders. However, ICP-AES analysis of powders revealed relatively low contents of iron of $12392 \mathrm{ppm}$. The strong peaks in field images are interpreted as linked to intensive weathering associated with the precepitation of goethite, hematite, specularite and manganese as well as intensive dedolomitization. Dedolomitization is indicated by calcitic spectra derived from the 
dolomite bodies. The spectral difference of laboratory and field spectra interferes significantly the application of laboratory spectra of powdered samples for the identification of dolomite bodies in the field. Furthermore, the process of late dedolomitization puts an additional challenge on the determination of dolomite bodies. Due to these strong spectral variations between laboratory and field spectra, we recommend that the mapping approaches should not solely rely on spectral algorithms but also consider normal light field panoramas and representative outcrop analysis. We also note that the quality of resolution is too low for the determination of small-scale variations of diagenetic phases at distances larger than $4 \mathrm{~km}$. However, when the limitations mentioned are taken into account, hyperspectral imaging proves to be a powerful tool that helps in the determination of the distribution of diagenetic phases, even in challenging conditions.

\section{Introduction}

Several remote sensing techniques such as hyperspectral imaging were applied during recent years to determine the distribution of lithologies in geological exposures (Bierwirth, Huston, and Blewett 2002; Kruse 1988). Hyperspectral imaging may be the critical solution to investigate the architecture of inaccessible sedimentary and diagenetic units for, for example, quantitative reservoir studies; and it allows fast data acquisition over very large areas ( $\mathrm{km}$ scale). Hyperspectral imaging is based on the collection of spectral reflectance data in hundreds of spectral bands. For compositional determination studies, hyperspectral imaging is based on the fact that each mineral and even variations of one mineral yield characteristic spectral absorption features across the electromagnetic spectrum (van der Meer et al. 2012). In particular, airborne hyperspectral remote sensing is increasingly popular due to the quick acquisition of compositional information of the Earth surface in extensive areas (Chabrillata et al. 2010; Crósta and de Souza Filho 2000; Crouvi et al. 2006). However, the near vertical viewing geometry in airborne spectrometry constitutes an insurmountable challenge, for example, in mountainous terrains with vertical cliffs that can be much better assessed with ground-based techniques. Therefore, groundbased hyperspectral imaging was tested in carbonate quarries (e.g., Kurz et al. (2012)) at short distances to the cliff exposures.

In general, the separation of carbonate phases, such as dolomite and limestone, by hyperspectral imaging is enabled by slightly displaced absorption features in the spectra, as determined in several laboratory studies (Gaffey 1986; Clark et al. 1990; Windeler and Lyon 1991; Chester and Elderfield 1967; Hunt, Wisherd, and Bonham 1950; Adler and Kerr 1963; Huang and Kerr 1960). These clear spectral variations allow the determination of calcite and dolomite also in hyperspectral images captured in natural cliffs (Boesche et al. 2016) and in soils (Cozzolino and Morón 2003). In addition, hyperspectral imaging of field samples taken in known lithofacies in the study area proved to be advantageous for the spectral characterization of carbonate phases (Debba et al. 2005). This sampling approach resulted in several dolomite and 
calcite phases being distinguished on sample surfaces by Baissa et al. (2011). In the USA Beitler et al. (2007) took this approach a step further and presented a comparative study of hyperspectral data of cliffs and samples as well as of geochemical data for the study of sandstones. A relatively similar approach presented by Lagacherie et al. (2008) aimed to analyse carbonatic soils by combining laboratory, field and airborne hyperspectral measurements. Such method offers an effective way to validate lithological information derived from hyperspectral images through geochemical analysis and can aid in improved distinction between similar lithologies. However, the application of spectra collected from samples under laboratory conditions to natural cliffs in the field always faces the issue of weathering which often modifies significantly the geochemical composition of the parent rock. Younis et al. (1997) evaluated the influence of weathering on the spectral signature of limestones and other lithologies in semi-arid environments. However, a detailed evaluation of the effect of weathering on the detection of weathered dolomite in the field is still lacking. Therefore, here we present a study that demonstrates the opportunities and pitfalls of using hyperspectral images to identify dolomite bodies in a remote field location: the Central Oman Mountains, in the Sultanate of Oman. In the study area, additional challenges in the interpretation of hyperspectral images arise from transitional contacts between different limestone and dolomite phases (early and late diagenetic dolomite). For our study, we collected samples along a linear traverse across one accessible dolomite body at Wadi Mistal as suggested in the sampling approach of Gupta (2003). Unweathered parts of the samples were powdered and analysed for geochemistry and spectral characteristics. The goal was, firstly, to chemically characterise dolomite and limestone phases and to determine geochemical variations within the dolomite body, secondly, to evaluate the spectra with the aid of identifying characteristic absorption peaks and thirdly, to determine the degree of spectral variations within the dolomite phases. Fourthly, we aimed to evaluate the differences between dolomitic spectra in the powdered samples versus spectra in the natural cliffs revealing dolomite bodies, which was previously tested by van der Meer (1995) in other outcrops. The latter objective is driven by the fact that it is assumed that the dolomite bodies are extensively weathered at the cliff face but most likely in a variable manner which presumably impedes the determination of dolomite bodies in hyperspectral images more than previously assumed by van der Meer (1995). The presence of weathering processes affecting dolomite bodies is a documented phenomenon in the region (Beckert, Vandeginste, and John 2015) but the amount of variability in the weathering behaviour has not been evaluated yet. Fifthly, we examine the potential of the remote sensing technique to detect and characterise dolomite bodies from hyperspectral images captured at varying distances to cliff faces in the study area. The outcomes of our study enable us to elucidate the challenge of weathering in the interpretation of hyperspectral images for the mapping of dolomitic structures. 


\section{Location and characteristics of the study area}

The Central Oman Mountains constitute an integral part of the continental Arabian plate (Searle and Cox 1999) and reveal a well bedded layer-cake platform carbonate succession (Aigner and Dott 1990; Koehrer et al. 2012). The Jebel Akhdar (Fig. 1), located in the northern part of Oman, allows the study of these platform carbonates exposed in numerous wadis showing tens of metres high cliff faces. The solar radiation of $21.6 \mathrm{~m}^{2}$ day $^{-1}$ to $26.1 \mathrm{~m}^{2}$ day $^{-1}$ linked to a daily sunshine duration (n) of 9.0 to 9.7 hours (Siebert, Nagieb, and Buerkert 2007) provide excellent conditions for hyperspectral imaging in these wadis. Cloudy days are rare during March and April but the warm temperatures of $21.7^{\circ} \mathrm{C}$ to $42.1^{\circ} \mathrm{C}$ (Siebert, Nagieb, and Buerkert 2007) result in a challenging situation for the measuring equipment. In addition, the wadis experienced increased levels of average yearly rainfall $(330.15 \mathrm{~mm})$ recorded during 1977 to 2003 in comparison to, for example, the Northern Oman Mountains (98.37 mm in Wadi Al Hawasinah) (Kwarteng, Dorvlo, and Vijaya Kumar 2009). Such rare but heavy rain falls affect weathering behaviour of the Saiq Formation carbonates, the focus of this study. The Saiq Formation comprises Middle Permian units which represent a stratigraphic equivalent to the Lower Khuff Member in the U.A.E. and Kuwait and to the Lower Dalan Member in the Zagros Mountains of Iran (AlHusseini 2006). The carbonate succession was affected by two main phases of dolomitization resulting in the formation of an early dolomite (ED) (Vandeginste, John, and Beckert 2015; Coy 1997) and a late diagenetic dolomite (DT2) (Vandeginste, John, and Beckert 2015; Beckert, Vandeginste, and John 2015). The extension of other types of dolomite such as DT3 dolomite (Vandeginste, John, and Beckert 2015) is limited to a few metres.

\section{Methodology}

The procedure applied in this study involves three main steps. Firstly, hyperspectral imaging was used as a remote sensing tool to identify different lithologies in accessible and inaccessible outcrops. Secondly, the presence of lithologies derived from the hyperspectral images was validated with field mapping in several accessible representative outcrop in Wadi Mistal including geological descriptions and intensive sampling in one outcrop. Thirdly, potential geochemical variations indicated by variations in the absorption peak intensity present in spectra from hyperspectral images were quantitatively determined through ICP-AES analysis on samples taken in the geologically mapped outcrop in Wadi Mistal.

\section{Hyperspectral image analysis}


Ten cliff faces distributed across the Central Oman Mountains were selected to evaluate the presence of different lithologies and to determine the extent of the dolomitized areas (Table 1). A Pushbroom scanner system from Norsk Elektro Optikk AS (NEO) was used to capture cliff faces in the near infrared spectrum during March and April 2014. The scanner compiled spectral information along an array of linearly aligned detector elements which scanned a field of view (Schowengerdt, 2007) of 16 degrees. Pixel information in this field of view refers to the continuous spectrum, which is indicative and unique for every mineral phase. The high resolution of the camera system of $5.45 \mathrm{~nm}$ (288 bands in total) allowed the visualisation of smallscale changes in the continuous spectrum (wavelength $930 \mathrm{~nm}$ to $2500 \mathrm{~nm}$ ) of present lithologies. The built in MCT sensor (mercury cadmium telluride photoconductive detector) compiled spectral information with a maximum frame rate of 450 frames per second (fps) with a bit resolution of 16bit. The built in deep cooling system ensures that the impact of varying temperatures on the sensor during the day can be regarded as negligible.

Pre-processing of raw image files was conducted by Mapping Solutions Ltd. and focused on the calibration of the HySpex - SWIR $320 \mathrm{~nm}$ (short wave infrared) system and atmospheric and solar irradiance curve corrections.

The first step of the main image processing method conducted in this study involves the elimination of pixels lacking data values ( $\mathrm{NaN}$ [not a number]) or infinite pixels in the reflectance and radiance image of every outcrop. Due to the atmospheric impact on the amount of infinite pixels linked to the presence of clouds and the daytime of image capturing variable bands were erased from the hyperspectral images. In most images the bands 35, 37, 74-95, 158-187, 195, 245, 265 and 274-288 were eliminated and were no longer taken into consideration during further image processing. However, some images allowed more bands to remain incorporated in the hyperspectral image (Table 1). All spectra presented in this study were smoothed with a Savitzky-Golay filter.

As a second step, a principal component analysis (PCA), an independent component analysis (ICA) and a minimum noise fractionation (MNF) analyses were conducted on all reflectance and radiance images. The determination of noisy bands provide the base for numerical methods to identify bands lacking spectral overlaps. Further numerical processing focussed only on 20 bands of PCA, ICA and MNF containing valuable information. Subsequently a numerical separation of visually defined regions of interest was applied based on band math's calculations. Numerical operations were always conducted by considering the maximum and minimum deviation of the absolute reflectance and radiance value in every band derived from the absolute difference of pixels in the region of interest. As a final step, all band math calculations were executed in a decision tree in order to obtain a reliable well-defined distribution of lithologies present in all images incorporated in this study.

The decision tree procedure as a supervised principle of classification (active definition of certain endmembers) was preferred to unsupervised types of classification such as $\mathrm{K}$ means or iterative self- organising data methods during image processing. Numerous series of trial classifications conducted with unsupervised 
methods revealed significant misclassifications of endmembers, not fully applicable to the distribution of lithologies observed in the field.

\section{Field mapping and sampling}

Hammer and chisel were used to take 34 representative samples of the most prominent lithologies present in the study area (Fig. 2) along a transect in one accessible outcrop in Wadi Mistal (Fig. 3A and B). The hyperspectral image collected from this outcrop is named Wadi Mistal-W-01-a. This outcrop comprises most of the lithologies determined in the hyperspectral images and additionally enabled the sampling of a transect across different dolomitized units (Fig. 3A and B). In order to determine the presence and arrangement of iron rich and iron poor dolomite and calcite phases, all hand samples were stained following a modified procedure of Dickson (1966) as described in Beckert, Vandeginste, and John (2015).

\section{Geochemical analysis with ICP-AES}

The 34 samples taken in Wadi Mistal were analysed by inductively coupled plasma atomic emission spectroscopy (ICP-AES) to gain information on the elemental composition of the studied limestones and dolomites in the outcrop in Wadi Mistal (Fig. 3C). Measurements were conducted with a Thermo iCap 6500 Duo at the Natural History Museum in London. All samples were cut with a saw and crushed with a hammer. Pure pieces of one phase (lacking veins or weathering products such as iron oxides or hydroxides) were collected and powdered with pestle and mortar until $200 \mathrm{mg}$ of powder could be achieved from every sample. The powders were dissolved by addition of $30 \mathrm{ml}$ of $5 \% \mathrm{HNO}_{3}$ to ensure a gentle reaction of the powder with the acid and heated to $80^{\circ} \mathrm{C}$ for one hour. Subsequently, the solutions were filtered and the filtrate on the filter paper dried to determine the weight of the insoluble residue which is subtracted from the original amount of sample powder of $200 \mathrm{mg}$ in order to determine elemental concentrations from the carbonate phase. 5\% $\mathrm{HNO}_{3}$ was added to the filtered solution to obtain $50 \mathrm{ml}$. Based on the very high concentrations of calcium and magnesium in the solution, a dilution series was prepared subsequently to ensure exact results during later ICP-AES measurements. Dilutions contained $0.2 \mathrm{ml}$ of the original solution and $9.8 \mathrm{ml} 5 \% \mathrm{HNO}_{3}$. All solutions were prepared up to 3 days before the analysis and kept fresh in a refrigerator. In addition, powdered dolomite (GBW07114) and calcite (CRM752) standards were prepared in the same way as the samples to determine the reproducibility of the results. The analytical precision of measured limestone standards ranged from up to 5 $\%$ for calcium, magnesium and strontium to a maximum of $2 \%$ for iron and manganese. Replicate analysis conducted on dolomite standards revealed a precision of $5 \%$ for calcium, magnesium and strontium and $3.5 \%$ for iron and manganese. 


\section{Results}

The results obtained during this study are presented in two sections. The first section deals with the lithological as well as geochemical characteristics of all lithologies present in hyperspectral images and in the outcrop in Wadi Mistal. The second section focuses on 1) the hyperspectral characteristics of lithologies studied, 2) differences between spectra collected in outcrops and in the laboratory and 3) the impact of varying distances to the outcrops on the determination of dolomite bodies in hyperspectral images.

\section{Lithological and chemical characteristics of observed lithologies}

Macroscopic features of the lithologies

The studied stratigraphic interval reveals 7 different lithologies although not all lithologies are present in every outcrop. The lithologies are presented in their stratigraphic order ranging from Precambrian to Permian times (Table 2) and differ in composition with respect to siliciclastic and carbonate content. Carbonate lithologies are distinguished by the content of marl in the limestones and by the type of dolomitization which affected the platform carbonate succession. Lithologies were identified through field mapping as well as sampling and can be distinguished in hyperspectral images.

Precambrian rocks can be grouped into shales and sandstones. Shales show brownish to purple colours in the field and often directly underlie Permian carbonates in the Central Oman Mountains (2A). Depending on the content of quartz in the layers, this lithology forms ridges resistant to weathering. Precambrian sandstones are restricted to a few outcrops in Wadi Mistal and Wadi Sahtan and commonly occur as thin layers of up to $3 \mathrm{~m}$ in thickness. The colour ranges from light to dark brown and often appears similar to DT2 dolomite from the distance. One accessible sandstone bed in Wadi Sahtan consists of rounded quartz grains with a maximum diameter of $0.2 \mathrm{~cm}$ and a quartzitic matrix with brownish iron crusts.

Massive limestones comprise mud- to packstones with a low content of stylolites (Fig. 2B). Bendias et al. (2013) mapped the characteristics of these Permian limestones in detail and presented logs taken in Wadi Mistal and Sahtan. The fossil content varies from bed to bed and reveals a typical open to shallow marine fauna including rugose corals, crinoids, bivalves and gastropods. Massive limestones range in colour from medium to dark grey with a bed thickness decimetric to metric in scale.

Marly limestones occur as several laterally continuous beds present within $20 \mathrm{~m}$ above the Precambrian/ Permian unconformity and are characterized by a carbonaceous marl composition with flaser structures (Fig. 2C). The fossil content is strongly reduced as opposed to the increased content of stylolites. Due to similar bed thicknesses and colours, massive and marly limestones can only be distinguished on hyperspectral images in inaccessible outcrops but not on normal light field photographs. 
Early diagenetic dolomite (ED dolomite) reveals a brownish weathering colour; and ED dolomite is fabric preserving with respect to fossils such as crinoids, bivalves and rugose corals (Fig. 2D). This type of dolomite is identical with D2 dolomite defined by Coy (1997) and ED dolomite presented in Beckert, Vandeginste, and John (2015). ED dolomite occurs as a massive dolomitized zone with a thickness of several hundreds of metres and a kilometre wide lateral extent. ED dolomite can be found in Permian to Triassic beds in all the selected wadis analysed in this study in the Central Oman Mountains. Contact zones between ED and limestone appear sharp with wavy to bedding parallel shapes.

Late diagenetic dolomite (DT2 dolomite) is characterised by a reddish weathering colour and medium to dark grey colours on fresh surfaces (Fig. 2D, E and F). The contact zones of DT2 dolomite to the undolomitized limestone host rock appear sharp, whereas contact zones to ED dolomite are commonly of a transitional nature (Fig. 2D). As a common feature in all analysed outcrops, the base of DT2 dolomite bodies is often aligned with marly limestone beds. The maximum lateral extent of DT2 dolomite bodies observed in the images amounts to $1 \mathrm{~km}$, whereas the maximum vertical thickness is several tens of meters. DT2 dolomite bodies often occur as lenses revealing various morphologies. This type of dolomite is similar to D3 and D4 dolomite presented by Coy (1997) and DT2 dolomite shown in Beckert, Vandeginste, and John (2015).

Very late diagenetic dolomite (DT3 dolomite) occurs only in Wadi Mistal and is restricted to the northern and western flanks of the Wadi structure (Fig. 2F). Vandeginste et al. (2013) defined this type of dolomite as fracture related with brick red weathering colours. The lateral and vertical extent of DT3 dolomite is restricted to a few metres.

Elemental composition of massive limestones, DT2 and ED dolomite

The elemental composition was determined by analysing powdered samples taken along a transect in Wadi Mistal (yellow line in Fig. 3). The calcium, magnesium, iron, manganese and strontium contents of all 34 samples are given in the table in Fig. 3C and Fig. 5 displays the elemental variations as a plot in function of distance along the transect through the stratigraphy. The stratigraphic sample position of 12 of these samples (marked in bold italic in Fig. 3C) was also used for later spectral sampling (e.g., in Fig. 7) to allow comparisons between geochemical and spectral results.

The calcium and magnesium content shows a strong change at the contact between limestone and DT2 dolomite (Fig. 4) with a decrease from $38.4 \%$ to $22.6 \%$ for calcium and an increase from $0.9 \%$ to $11.8 \%$ for magnesium content. Within the DT2 dolomite body, calcium (21.4\% to $24.2 \%)$ and magnesium (11.4 \% to $12.5 \%)$ remain both at the same level and lack a significant decreasing or increasing trend.

Iron and manganese show similar trends and have very low values in limestones (5 ppm to $300 \mathrm{ppm}$ ) and ED dolomite (5 ppm to $140 \mathrm{ppm}$ ). In comparison, within the DT2 dolomite body iron and manganese strongly increase (iron up to $12000 \mathrm{ppm}$ and manganese up to $4600 \mathrm{ppm}$ ) and show a dominantly decreasing trend towards ED 
dolomite. Furthermore, it is of interest to note that the highest peak in iron and manganese occurs $3.35 \mathrm{~m}$ above the limestone - DT2 dolomite contact. Within this zone of $3.35 \mathrm{~m}$ iron increases from $1000 \mathrm{ppm}$ to $12000 \mathrm{ppm}$ and manganese from $1800 \mathrm{ppm}$ to $4600 \mathrm{ppm}$.

Strontium content shows a dominant peak within the limestone and remains at a relatively constant level within the DT2 dolomite body. The strongest strontium peak of $1400 \mathrm{ppm}$ occurs in one limestone bed $13.05 \mathrm{~m}$ below the contact between limestone and DT2 dolomite.

Weathering of late diagenetic dolomite phases (DT2 dolomite)

Field characteristics

Alteration was mainly observed in DT2 and ED dolomite, whereas massive limestones lack a significant weathering trend.

Alteration of DT2 dolomite associated with the precipitation of alteration products occurs within a millimetre to centimetre wide zone. Unaltered DT2 dolomite usually reveals medium to coarse crystalline dolomite rhombs and saddle dolomite in fractures and veins as well as an infilling of vugs (Fig. 5A). Partially altered DT2 dolomites reveal dedolomite rims or patches in and along fractures and veins (Fig. 5B). The presence of dedolomite was determined by comparing the appearance of stained hand samples with similar weathered dolomites described in Beckert, Vandeginste, and John (2015). Saddle dolomite is also often replaced by dedolomite. Heavily altered DT2 dolomites display a completely dedolomitized fabric associated with the presence of goethite (Fig. 5C). In contrast to the first three cases, Fig. 5D and E show altered DT2 dolomite characterised by the intense precipitation of minerals such as hematite, pyrite and specularite. Furthermore, goethite and manganese were also found in association with dedolomite in case of heavily altered specularitic DT2 dolomite (Fig. 5E). Alteration of dolomite bodies in the Oman Mountains has also been observed in carbonates of Jurassic age by Vandeginste and John (2012) associated with the precipitation of goethite and manganese and interpreted as resulting from meteoric weathering during the Pleistocene.

\section{$\underline{\text { Carbon and oxygen stable isotope results }}$}

The carbon and oxygen stable isotope signature of unweathered DT2 dolomite ranges between $-2.5 \%$ o to $-6 \%$ VPDB for $\delta^{18} \mathrm{O}$ and 2.9\% to 4.8\% VPDB for $\delta^{13} \mathrm{C}$ (Fig. 6 gray box according to Beckert, Vandeginste, and John (2016). In comparison, altered DT2 dolomite shows strongly depleted carbon values $\left(\delta^{13} \mathrm{C}:-0.45 \%\right.$ to $-8.42 \%$ o VPDB) (Fig. 6 group 1) whereas oxygen shows no significant difference from unweathered DT2 dolomite. The majority of samples in this group show $\delta^{13} \mathrm{C}$ values lighter than $-4 \%$ VPDB. A second group of weathered samples is characterised by more negative $\delta^{13} \mathrm{C}$ and $\delta^{18} \mathrm{O}$ values $\left(\delta^{18} \mathrm{O}\right.$ below $-6 \%$ VPDB) (Fig. 6 group 2). In 
group 2 strongly depleted oxygen values ( $\delta^{18} \mathrm{O}:-6.5 \%$ VPDB) seem to be related to $\delta^{13} \mathrm{C}$ values heavier than $-4 \%$ VPDB.

\section{Spectral characteristics of lithologies observed in hyperspectral images}

The hyperspectral images Wadi Mistal-W-01-a and Wadi Mistal-E-06-c (Table 1) were used to compare absorption peaks present in spectra of all lithologies (Table 2). Marly limestones, DT2 and DT3 dolomite show a very strong absorption at $1003 \mathrm{~nm}$. In addition, marly limestones and DT3 dolomite comprise an absorption peak at 1230 $\mathrm{nm}$ which is absent in other spectra (Fig. 7). At $1948 \mathrm{~nm}$, Precambrian shales and sandstones are characterised by an absorption peak which is not present in spectra derived from Permian lithologies. Precambrian sandstones contain additionally absorption peaks at $2002 \mathrm{~nm}$ and $2197 \mathrm{~nm}$ (Fig. 7). Marly limestones show a prominent absorption at $2153 \mathrm{~nm}$ whereas massive limestones contain an absorption peak at $2330 \mathrm{~nm}$. ED, DT2 and DT3 dolomite reveal a prominent absorption at 2310 $\mathrm{nm}$. Precambrian shales and sandstones lack these prominent carbonatic absorptions, but reveal an absorption at $2375 \mathrm{~nm}$ (Fig. 7).

Spectral characteristics of massive limestone, DT2 and ED dolomite collected in hyperspectral images along the sampled transect in Wadi Mistal

In order to evaluate potential variations in the absorption peak position and depth, twelve sampling locations along the transect of geochemical samples (Fig. 3A and B) were chosen (marked in bold italic in Fig. 3C) for spectral sampling. Spectra of massive limestones show relatively similar absorption peaks with minor variations in the reflectance intensity (Fig. 8A). As a typical feature, a strong absorption peak is always present at $2330 \mathrm{~nm}$. In comparison to DT2 dolomite, massive limestone as well as ED dolomite contain an absorption peak at $2003 \mathrm{~nm}$ in the spectra.

DT2 dolomite reveals minor variations in the presence and depth of absorption peaks across the dolomite body. Strong peaks $(1003 \mathrm{~nm})$ are evident in lower areas of the DT2 dolomite body (spectral sampling positions similar to MPA 12A, MAP13B and MPA18), whereas the top shows weaker absorption peaks (MPA26) (Fig. 8A and B). Stratigraphically lower areas of the DT2 dolomite body reveal also an absorption peak at $1230 \mathrm{~nm}$. The uppermost part of the dolomite body (MPA33) contains a strong absorption peak at $1970 \mathrm{~nm}$ occurring only as a weak absorption in all other spectra and lacking in the spectrally sampled area MPA14. All DT2 and ED dolomite spectra are characterised by an absorption peak at $2310 \mathrm{~nm}$ (Fig. 8C).

The spectra of ED dolomite is different to DT2 dolomite as it lacks an absorption around $1003 \mathrm{~nm}$.

Spectral characteristics of unaltered massive limestone, DT2 and ED dolomite powders collected under laboratory conditions along the sampled transect 
Spectral characteristics of weathered DT2 dolomite bodies collected in hyperspectral images across the Central Oman Mountains

Ten different outcrops showing DT2 dolomite bodies distributed across the Central Oman Mountains were chosen to evaluate potential variations in the characteristics of DT2 dolomite spectra (Table 1).

The spectra show strong differences in the presence and depth of absorption peaks. All dolomite bodies reveal an absorption peak at $1003 \mathrm{~nm}$ except for two dolomite bodies in the western area of Wadi Sahtan (Wadi Sahtan-W-07-a and Way to Yasib02-re) and two in Wadi Mistal (Wadi Mistal-W-16-c and Wadi Mistal-E-06-c) (Fig. 10). The spectra of Wadi Sahtan-W-07-a and Wadi Mistal-E-02-a also lack an absorption peak at $1133 \mathrm{~nm}$ which is present in all other spectrally sampled DT2 dolomite bodies. At $1230 \mathrm{~nm}$ only Wadi Mistal-E-02-a shows an absorption peak and at $1970 \mathrm{~nm}$ Wadi Mistal-E-02-a and Wadi Mistal-W-01-a reveal absorptions (Fig. 10). From $1997 \mathrm{~nm}$ to $2008 \mathrm{~nm}$ all dolomite bodies are characterised by absorption peaks except for two dolomite bodies in Wadi Mistal (Wadi Mistal-W-01-a and Wadi Mistal-W-11-a). Wadi Mistal-W-11-a shows together with Wadi Mistal-E-02-a an absorption peak at 2018 which lacks in all other dolomite bodies (Fig. 10). Interestingly, all dolomite bodies show typical dolomite absorptions at $2310 \mathrm{~nm}$ with the exception of Wadi Mistal-W-11-a and Wadi Mistal-W-07-a. Both spectrally sampled dolomite bodies contain absorption peaks at $2330 \mathrm{~nm}$ indicating a calcitic composition. 


\section{Differences in the detection of DT2 dolomite bodies at varying distances to the cliff face}

The overview panorama presented in Fig. 11A was captured at $5 \mathrm{~km}$ to $9 \mathrm{~km}$ distance to the cliff faces and shows only remnants of DT2 dolomite bodies lacking any detailed geometries. This results in an undetailed scale of the image of 1:18500 (measured in the area $\mathrm{E}$ and $\mathrm{C}$ in Fig. 11A) and thus, dolomite bodies of less than about 5 meter in height are below the image resolution. However, even the relatively thick vertical extension of the dolomite body $\mathrm{W}-07-\mathrm{a}$ of $50 \mathrm{~m}$ results only in 10 pixel in image (vertical image extension 384 pixel) which is not sufficient to determine shape characteristics (Table 3).

Improved accuracies of detection have been recorded at smaller distances of $1 \mathrm{~km}$ to 4 $\mathrm{km}$. For example, the most distant outcrop $(8.96 \mathrm{~km})$ indicated as B in Fig. 11A was recaptured with a distance of $3.29 \mathrm{~km}$ (result shown in Fig. 11B). The resolution of the image (1:8990) allows the detection and rough characterization of the dolomite bodies in the centre of the image with respect to shape and dimension. The locally 25 $\mathrm{m}$ thick dolomite body can be determined in the hyperspectral image thanks to a smaller size of the pixel of $2.3 \mathrm{~m}$ by $2.3 \mathrm{~m}$ (Table 3 ).

At distances lower than $350 \mathrm{~m}$ the pixel size is of $0.43 \mathrm{~m}$ by $0.43 \mathrm{~m}$ in $\mathrm{W}-01-\mathrm{a}$ or 0.79 $\mathrm{m}$ by $0.79 \mathrm{~m}$ in W-08-a (Table 3 ). Patches of DT2 dolomite of only several meters are evident in the interpreted images (Fig. 11D and E) and transitional contact zones between different types of dolomite are evident.

\section{Discussion}

\section{Evaluation of laboratory and field spectra}

\section{Geochemical characteristics of field spectra}

The evaluation of spectra collected in the field focussed on DT2 dolomite bodies and the surrounding host rock. In detail, variations in the spectra of various DT2 dolomite bodies across the Central Oman Mountains were studied.

\section{DT2 dolomite bodies:}

The carbonate composition of DT2 dolomite bodies is indicated by the presence of characteristic combination and overtone bands of the planar carbonate ion. The observed strong absorption peak around $2330 \mathrm{~nm}$ refers to the $3 v_{3}$ overtone vibrational mode, whereas the $2 v_{1}+2 v_{3}$ vibrational mode causes an absorption observed at $1975 \mathrm{~nm}$ (sensu Clark et al. (1990)). However, the internal separation between different carbonate phases is a more challenging task due to subtle shifts in the spectra that are often difficult to capture in field images due to a limited spectral resolution of $5 \mathrm{~nm}$. Therefore additional peaks were used to detect dolomite bodies derived by comparisons with other studies. Gaffey (1987) recognised typical 
dolomitic absorptions at 2319, 2244, 2165, 1979 and $1740 \mathrm{~nm}$, and such absorptions appear at similar positions $(2310,2245,2164,1975$ and 1738) in spectra of the DT2 dolomite bodies. The absorption peak located at $2310 \mathrm{~nm}$ is the most indicative peak for DT2 dolomite whereas the limestone host rock always shows a prominent absorption at $2330 \mathrm{~nm}$. Furthermore, DT2 dolomite bodies could be determined by the presence of a typical absorption at $1135 \mathrm{~nm}$ which was also recognised by Adler and Kerr (1963) in measured dolomite samples. All dolomite bodies reveal this absorption peak with the exception of Wadi Sahtan-W-07-a and Wadi Mistal-E-02-a. Interestingly, Wadi Mistal-W-11-a and Wadi Mistal-W-07-a lack absorptions at 2310 $\mathrm{nm}$ but contain an absorption peak at $2330 \mathrm{~nm}$ indicating a calcitic composition. The calcitic composition of the dolomite body in Wadi Mistal-W-11-a is furthermore supported by an absorption peak at $1997 \mathrm{~nm}$ which was also detected by Gaffey (1987) at $1999 \mathrm{~nm}$ in calcite samples. The presence of calcite absorptions in dolomite bodies is assumed to be associated with weathering and dedolomitization which is discussed later.

Furthermore, spectra taken from the dolomite bodies reveal several substitutions with other major cations such as iron. The presence of iron is indicated by a strong absorption peak located at $1003 \mathrm{~nm}$ (sensu Ballhausen (1962) and Burns (1993)). Variations in the peak intensity in general refer to variations in the roughness of the outcrop surface caused by different grain or mineral sizes. Visual observations of cliff faces revealed dolomite crystals of up to $0.5 \mathrm{~cm}$ which results in strongly reduced brightness and less deep absorption peaks in comparison to fine grain sizes (Gaffey 1987, 1986; Crowley 1986). Iron occurs firstly, in a divalent state in association with magnesium carbonate. Typical spectra indicating the presence of siderite and thus the combination of iron and carbonate without magnesium were not found. Secondly, field observations show iron in association with for example goethite and hematite. Due to the lack of copper minerals in the outcrop, the effect of copper on the presence of these absorptions around $1000 \mathrm{~nm}$, as for example observed by Holmes and McClure (1957) and Bjerum, Ballhausen, and Klixbüll Jørgensen (1954), can be regarded as negligible. ICP-AES measurements of unaltered sample powders support the presence of iron in DT2 dolomite showing concentrations of $2100 \mathrm{ppm}$ to 12000 ppm (Fig. 3C). Along the sampled transect, spectra of unaltered dolomite powders lack any evidences for a decrease in the iron concentration towards the top of the dolomite body as indicated by ICP-AES measurements. It is assumed that the concentration of iron is not high enough to result in strong spectral variations.

Several dolomite bodies are characterised by an absorption peak at $2008 \mathrm{~nm}$ except for two bodies in Wadi Mistal (Wadi Mistal-W-01-a and Wadi Mistal-W-11-a). This absorption indicates the presence of zinc, as for example recognised by Gaffey (1987) in smithsonite. However, smithsonite was not macroscopically determined in outcrops and thus, a fine distribution of zinc in the dolomite matrix in several dolomite bodies is more likely.

\section{Host rock:}


Massive limestones were clearly identified by the presence of a strong absorption peak at $2330 \mathrm{~nm}$ indicative for calcite (sensu Gaffey (1987) and Clark et al. (2003)). In addition, the limestone sample WS272 in the USGS spectra library reveals this absorption peak at $2330 \mathrm{~nm}$.

Marly limestones show a prominent absorption at $2153 \mathrm{~nm}$. This absorption is formed by the accumulation of clay rich absorption seams. The presence of iron in marly limestones and DT3 dolomite is indicated by strong absorptions around $1003 \mathrm{~nm}$ supported by rusty weathering colours in outcrops.

The dolomitic composition of ED dolomite is demonstrated by the presence of a typical dolomite absorption at $2310 \mathrm{~nm}$ in comparison to the dolomite sample HS102.3B listed in the USGS spectra library and Gaffey (1987). This absorption occurs also in the spectra of DT3 dolomite. The absence of an iron absorption around $1003 \mathrm{~nm}$ forms one the major differences between ED and DT2 dolomite.

Precambrian shales and sandstones show an absorption at $2375 \mathrm{~nm}$. Additionally, absorption peaks occur at $2002 \mathrm{~nm}$ and $2197 \mathrm{~nm}$ indicating a quartzitic composition as similarly shown by the sample HS117.3B in the USGS spectra library.

Geochemical characteristics of laboratory spectra

Compared to weathered cliffs, spectra from unaltered powder samples reveal two peaks indicating a calcitic or a dolomitic composition instead of one, depending on the sample type. Massive limestones show absorptions at $2290 \mathrm{~nm}$ and $2334 \mathrm{~nm}$ (in the field only $2330 \mathrm{~nm}$ is evident), whereas DT2 and ED dolomite reveal absorptions at $2266 \mathrm{~nm}$ and $2315 \mathrm{~nm}$ (in the field only $2310 \mathrm{~nm}$ is evident) (Fig. 9B). The determination of this additional peak in limestones and dolomites is enabled by the increased spectral resolution of $1 \mathrm{~nm}$. In comparison, field spectra only have a resolution of $5 \mathrm{~nm}$ and thus lack these spectral details. Spectra of powdered samples also do not show an iron absorption peak at $1003 \mathrm{~nm}$, a very prominent peak in field spectra. In addition, peaks at $1970 \mathrm{~nm}$ and $2003 \mathrm{~nm}$ were also only observed in weathered dolomite bodies. Spectra of powdered samples lack variations in the depth of absorption peaks across the DT2 dolomite body which relates to the homogeneity of the sample powder with respect to grain size (sensu van der Meer (1995)).

\section{Weathering is the main challenge in the applicability of lab rock powder spectra to the study of natural cliffs}

Spectra from unaltered powder samples and altered natural cliffs of similar lithofacies types reveal major differences. Most DT2 dolomite bodies present in natural cliffs are characterised by strong iron absorptions and often show calcitic instead of dolomitic absorptions. This can only be explained by alteration (weathering) and dedolomitization of the exposed cliff surface.

As observed in hand samples and other local studies (Beckert, Vandeginste, and John 2015) alteration (weathering) of DT2 dolomite is associated with the transformation of DT2 dolomite into dedolomite accompanied with the precipitation of goethite, 
hematite, specularite and also pyrite (Fig. 5). The intensity of weathering depends on the time of exposure and meteoric fluid flow and varies within the analysed outcrops. Outcrops affected by recent rock fall reveal completely unaltered DT2 dolomite that differs heavily from the spectra of outcrops with an exposure time of hundreds of years (for comparison Way to Yasib-02-re (barely weathered) and Wadi Mistal-W01-a (heavily weathered) - Fig. 7).

The process of dedolomitization is supported by stable isotope results which indicate the presence of two different groups. In comparison to unaltered DT2 dolomite (Fig. 6 gray box) $\left(\delta^{13} \mathrm{C}: 2\right.$ to $5 \%$ VPDB and $\delta^{18} \mathrm{O}:-2$ to $-6 \%$ VPDB $)$, the majority of altered samples (group 1) show a depletion only in carbon $\left(\delta^{13} \mathrm{C}\right.$ : -0.5 to $-6 \%$ VPDB) whereas oxygen values are relatively invariant $\left(\delta^{18} \mathrm{O}:-2\right.$ to $-6 \%$ VPDB $)$. A similar trend was observed by Nader, Swennen, and Keppens (2008) in dedolomitized carbonates; and Allan and Matthews (1982) and Lohmann (1988) interpreted this trend as a characteristic feature of fresh water meteoric environments. Stable isotope results obtained from dolomite bodies hosted in Jurassic rocks in Oman (Vandeginste and John 2012) reveal a similar depletion trend and were interpreted as a pseudomorphic replacement of dolomite by calcite triggered by weathering involving rain water. Due to similar geochemical signatures and equal environmental conditions it can be assumed that the conclusion of Vandeginste and John (2012) presented for DT3 dolomite is also valid for dedolomitization of DT2 dolomite bodies hosted in Permian platform carbonates.

A minority of samples (group 2) reveals depleted carbon $\left(\delta^{13} \mathrm{C}\right.$ values of up to $-8 \%$ VPDB) and depleted oxygen $\left(\delta^{18} \mathrm{O}\right.$ more negative than $-6 \%$ VPDB $)$ values. Nader, Swennen, and Keppens (2008), Sanz-Rubio et al. (2001) and Cantrell, Al-Khammash, and Jenden (2007) linked those values $\left(\delta^{18} \mathrm{O}:-11 \%\right.$ to $-6 \%$ VPDB and $\delta^{13} \mathrm{C}:-8 \%$ to $-6 \%$ VPDB) also to dedolomitization triggered by meteoric fluids. However, only intense convection cells such as during monsoonal periods result in such depleted ${ }^{18} \mathrm{O}$ (Burns et al. 2001). Thus, those samples may indicate very wet periods where the intertropical convergence zone was located in more northern areas compared to the present position resulting in strong rainfalls in Oman. These cyclic wet periods associated with Indian Ocean monsoons were interpreted by Burns et al. (2001) derived from cave deposits in northern Oman.

Dedolomitization is also assumed to trigger the precipitation of iron oxides in weathered DT2 dolomite bodies due to chemical weathering and oxidation effects (Zeidan and Basyuni 1998). Compared to ED dolomite and limestone, unaltered dolomite shows an iron content ranging from $200 \mathrm{ppm}$ to $12000 \mathrm{ppm}$ (Fig. 3C) which is unevenly distributed (Fig. 4). Although this iron content in unweathered samples is not high enough to result in strong iron peaks in the spectra (lack of iron peak in Fig. 9) it is assumed to be sufficient to enable the precipitation of iron oxides under certain conditions. The oxidizing conditions during rainy periods may result in the destabilization of DT2 dolomite resulting in $\mathrm{Fe}^{2+}$ rich solutions. Due to fluid neutralization the $\mathrm{pH}$ increases and iron oxides precipitate based on the Eh-pH phase diagram of Grosz et al. (2006). Field observations show the dominant presence of goethite $\left[(\mathrm{FeO}(\mathrm{OH})]\right.$ in altered DT2 dolomite cliffs whereas hematite $\left(\mathrm{Fe}_{2} \mathrm{O}_{3}\right)$ occurs 
less frequently. This is due to the fact that goethite is considered to be more stable at low temperature conditions compared to hematite (Langmuir 1996).

These strong chemical variations between altered and unaltered dolomite bodies potentially result in significant challenges in supervised hyperspectral image classifications. The effect of weathering eliminates or shifts absorption peaks critical for the determination of dolomite bodies and often even dolomitic absorption peaks are absent in weathered dolomite bodies in the field. Furthermore, the heterogeneous distribution of, for example, iron in dolomite bodies (Fig. 4) potentially results in irregularly shaped weathering patterns which makes supervised classifications even more challenging.

\section{Potential of hyperspectral imaging for the detection of dolomite bodies as a function of distance to the cliff face}

The detection of DT2 dolomite bodies in hyperspectral images depends strongly on the distance between the hyperspectral camera system and the cliff face. A capturing distance of $5 \mathrm{~km}$ to $9 \mathrm{~km}$ is associated with a strong decrease of information that can be obtained from the image. Dolomite bodies of less than $50 \mathrm{~m}$ in thickness (Table 3) appear only as a few pixels in the image and lack most of the important information regarding shape and geometry. This implies that a survey using, for example, an aeroplane with a flight height above $5 \mathrm{~km}$ would not be able to image these bodies. In addition, the observation angle limits the scope to detect and characterise the dolomitized zones. Most of the DT2 dolomite bodies occur along nearly vertical cliff faces and thus, would often stay undetected from the air assuming viewing directions perpendicular to the earth surface. In these terrains ground based imaging is a more powerful tool and expands the scope of remote sensing (Kurz et al. 2012). The information retrieval is even increased in case of shorter distances to the cliff which improves the detection of smaller structures. In this study, the rough characterization of dolomite bodies was enabled at distances lower than $4 \mathrm{~km}$. With respect to reservoir analogue studies, the resolution and precision of the dolomite body dimensions from such data is assumed to be sufficient to set up reservoir models. However, detailed shape characteristics and variations in absorption peaks could only be determined more accurately at distances of less than $350 \mathrm{~m}$. Even metre sized patches of DT2 dolomite are evident in the interpreted images (Fig. 11D and E) and characteristics of contact zones to the surrounding host rock appear in detail.

\section{Conclusion}

The determination and characterisation of lithological heterogeneities in platform carbonate settings are highly important for mapping projects, especially in campaigns aiming to establish analogue models for subsurface reservoirs. During the last decades, inaccessible outcrops in the study area resulted in a lack of spatially 
distributed geochemical data in these reservoir models. Remote sensing techniques such as hyperspectral imaging bridge this issue by determining spectra indicative for lithologies and thus, enable the collection of relevant information even from inaccessible outcrops.

This paper presented a ground based hyperspectral mapping approach focussed on the detection of DT2 dolomite bodies in vertical cliffs in the Central Oman Mountains. The technique enabled the clear detection of dolomite bodies supported by visual comparisons with field panoramas and exemplary tests of spectrally mapped areas in the field. Lithologies hosting the dolomite bodies are of Precambrian and Permian age. In Precambrian units, shaly and sandy layers could be determined. Permian carbonates are partly dolomitized and reveal different limestones as well as ED, DT2 and DT3 dolomite. Due to its high content of iron, DT2 dolomite bodies differ spectrally from the other types of dolomite (ED dolomite). However, the study revealed strong variations in the spectra of DT2 dolomite across the Central Oman Mountains which is linked to weathering and dedolomitization. The latter transforms the dolomite spectra into a calcite spectra and makes the interpretation of pixel challenging. Furthermore, we evaluated the differences between spectra collected across one dolomite body in the field and spectra of powdered samples from similar sampling positions. The lack of weathering in powdered samples results in strong spectral differences and thus, spectra from powdered samples are limited in the use as reference spectra in supervised classifications to determine weathered dolomite bodies in field images.

\section{Acknowledgements}

This research project is funded by Qatar Petroleum, Shell, and the Qatar Science and Technology Park. We thank Mapping solutions Ltd. for their help during the acquisition of hyperspectral images and image pre-processing services. We also thank the Shuram Oil and Gas Logistics branch for providing logistical support during the collection of remote sensing data. Emma Williams from the Natural History Museum is thanked for her support in measuring samples with ICP-AES.

\section{References}

Adler, Hans H., and Paul. F. Kerr. 1963. "Infrared absorption frequency trends for anhydrous normal carbonates." Review of. The American Mineralogist 48.

Aigner, T., and R.H. Dott. 1990. Processes and Patterns in Epeiric Basins: Special Issues: Elsevier.

Al-Husseini, Moujahed. 2006. "Permian Arabian Tectono-Stratigraphic Chart." Review of. Geoarabia 11 (4):95-102. 
Allan, J. R., and R. K. Matthews. 1982. "Isotope signatures associated with early meteoric diagenesis." Review of. Sedimentology 29 (6):797-817. doi: 10.1111/j.1365-3091.1982.tb00085.x.

Baissa, Rachid, Kamal Labbassi, Patrick Launeau, Anne Gaudin, and Brahim Ouajhain. 2011. "Using HySpex SWIR-320m hyperspectral data for the identification and mapping of minerals in hand specimens of carbonate rocks from the Ankloute Formation (Agadir Basin, Western Morocco)." Review of. Journal of African Earth Sciences 61 (1):1-9. doi: http://dx.doi.org/10.1016/j.jafrearsci.2011.04.003.

Ballhausen, Carl J. 1962. Introduction to ligand field theory. First edition ed: McGraw Hill.

Beckert, Julia, Veerle Vandeginste, and Cedric M. John. 2015. "Exploring the geological features and processes that control the shape and internal fabrics of late diagenetic dolomite bodies (Lower Khuff equivalent Central Oman Mountains)." Review of. Marine and Petroleum Geology.

- - - 2016. "The role of dolomitization in the genesis of karst cavities in Permian platform carbonates (Lower Khuff - Oman) " Review of. Journal of Sedimentary Geology 342:165-79.

Beitler, Bowen, Brenda, Brigette A. Martini, Marjorie A. Chan, and William T. Parry. 2007. "Reflectance spectroscopic mapping of diagenetic heterogeneities and fluid-flow pathways in the Jurassic Navajo Sandstone." Review of. Aapg Bulletin 91 (2):173-90.

Bendias, D., B. Koehrer, M. Obermaier, and T. Aigner. 2013. "Mid-Permian Khuff Sequence KS6: Paleorelief-influenced facies and sequence patterns in the Lower Khuff time-equivalent strata, Oman Mountains, Sultanate of Oman." Review of. Geoarabia 18 (3):135-78.

Bierwirth, Phil, David Huston, and Richard Blewett. 2002. "Hyperspectral Mapping of Mineral Assemblages Associated with Gold Mineralization in the Central Pilbara, Western Australia." Review of. Economic Geology 97 (4):819-26. doi: 10.2113/gsecongeo.97.4.819.

Bjerum, Jannik, Carl J. Ballhausen, and Chr. Klixbüll Jørgensen. 1954. "Studies on absorption spectra I. Results of calculations on the spectra and configuration of copper (II) ions." Review of. Acta Chemica Scandinavica 8:1275-89.

Boesche, Nina K., Christian Rogass, Christian Mielke, Sabrina Herrmann, Friederike Körting, Anne Papenfuß, Christin Lubitz, Maximilian Brell, Sabine Tonn, and Uwe Altenberger. 2016. "Chapter 16 - Hyperspectral Rare Earth Element Mapping of Three Outcrops at the Fen Complex, Norway: Calcitic, Dolomitic, and Ankeritic Carbonatites A2 - Filho, Ismar Borges De LimaWalter Leal." In Rare Earths Industry, 235-65. Boston: Elsevier.

Burns, Roger G. 1993. Mineralogical applications of crystal field theory. Second Edition ed: Cambridge University Press.

Burns, Stephen J., Dominik Fleitmann, Albert Matter, Ulrich Neff, and Augusto Mangini. 2001. "Speleothem evidence from Oman for continental pluvial events during interglacial periods." Review of. Geology 29 (7):623-6. doi: 10.1130/0091-7613(2001)029<0623:sefofc>2.0.co;2. 
Cantrell, D., A. Al-Khammash, and P. D. Jenden. 2007. "Characterization and significance of dedolomite in Wadi Nisah, central Saudi Arabia." Review of. Geoarabia 12:15-30.

Chabrillata, S., P. C. Pineta, G. Ceuleneera, P. E. Johnsonb, and J. F. Mustard. 2010. "Ronda peridotite massif: methodology for its geological mapping and lithological discrimination

from airborne hyperspectral data." Review of. International Journal of Remote Sensing 21 (12):2363-88.

Chester, R., and H. Elderfield. 1967. "The application of infra-red absorption spectroscopy to carbonate mineralogy." Review of. Sedimentology 9:5-21.

Clark, Roger N., Trude V. V. King, Matthew Klejwa, Gregg A. Swayze, and Norma Vergo. 1990. "High spectral resolution reflectance spectroscopy of minerals." Review of. Journal of Geophysical Research: Solid Earth 95 (B8):12653-80. doi: 10.1029/JB095iB08p12653.

Clark, Roger N., Gregg A. Swayze, K. Eric Livo, Raymond F. Kokaly, Steve J. Sutley, J. Brad Dalton, Robert R. McDougal, and Carol A. Gent. 2003. "Imaging spectroscopy: Earth and planetary remote sensing with the USGS Tetracorder and expert systems." Review of. Journal of Geophysical Research: Planets 108 (E12):5131. doi: 10.1029/2002JE001847.

Coy, G. A. 1997. "Dolomitization of the Akhdar Group: The Arabian platform of Oman." Darwin College, Cambridge, United Kingdom.

Cozzolino, D., and A. Morón. 2003. "The potential of near-infrared reflectance spectroscopy to analyse soil chemical and physical characteristics." Review of. Journal of Agricultural Science 140:65-71.

Crósta, Alvaro Penteado , and Carlos Roberto de Souza Filho. 2000. "Hyperspectral remote sensing for mineral mapping: a case-study at alto Paraíso de Goías, central Brazil." Review of. Revista Brasileira de Geociências 30 (3):551-4.

Crouvi, Onn, Eyal Ben-Dor, Michael Beyth, Dov Avigad, and Rivka Amit. 2006. "Quantitative mapping of arid alluvial fan surfaces using field spectrometer and hyperspectral remote sensing." Review of. Remote Sensing of Environment 104 (1):103-17. doi: http://dx.doi.org/10.1016/j.rse.2006.05.004.

Crowley, James K. 1986. "Visible and near-infrared spectra of carbonate rocks: Reflectance variations related to petrographic texture and impurities." Review of. Journal of Geophysical Research: Solid Earth 91 (B5):5001-12. doi: 10.1029/JB091iB05p05001.

Debba, P., F. J. A. van Ruitenbeek, F. D. van der Meer, E. J. M. Carranza, and A. Stein. 2005. "Optimal field sampling for targeting minerals using hyperspectral data." Review of. Remote Sensing of Environment 99 (4):373-86. doi: http://dx.doi.org/10.1016/j.rse.2005.05.005.

Dickson, J. A. D. 1966. "Carbonate identification and genesis as revealed by staining." Review of. Journal of Sedimentary Research 36 (2):491-505. doi: 10.1306/74d714f6-2b21-11d7-8648000102c1865d.

Gaffey, Susan J. 1986. "Spectral reflectance of carbonate minerals in the visible and near infrared (0.35-2.55 microns): calcite, aragonite, and dolomite." Review of. American Mineralogist 71:151-62. 1987. "Spectral reflectance of carbonate minerals in the visible and near infrared (0.35-2.55 um): Anhydrous carbonate minerals." Review of. 
Journal of Geophysical Research: Solid Earth 92 (B2):1429-40. doi: 10.1029/JB092iB02p01429.

Grosz, S., A. Matthews, S. Ilani, A. Ayalon, and Z. Garfunkel. 2006. "Iron mineralization and dolomitization in the Paran Fault zone, Israel: implications for low-temperature basinal fluid processes near the Dead Sea Transform." Review of. Geofluids 6:137-53.

Gupta, R.P. 2003. Remote Sensing Geology: Springer Berlin Heidelberg.

Holmes, Owen G., and Donald S. McClure. 1957. "Optical Spectra of Hydrated Ions of the Transition Metals." Review of. The Journal of Chemical Physics 26 (6):1686-94. doi: doi:http://dx.doi.org/10.1063/1.1743606.

Huang, C. K., and Paul Kerr, F. 1960. "Infrared study of the carbonate minerals." Review of. The American Mineralogist 45.

Hunt, J. M., M. P. Wisherd, and L. C. Bonham. 1950. "Infrared Absorption Spectra of Minerals and Other Inorganic Compounds." Review of. Analytical Chemistry 22 (12):1478-97. doi: 10.1021/ac60048a006.

Koehrer, Bastian, Thomas Aigner, Forke Holger, and Michael Pöppelreiter. 2012. "Middle to Upper Khuff (Sequences KS1 to KS4) outcrop-equivalents in the Oman Mountains: Grainstone architecture on a subregional scale." Review of. Geoarabia 17 (3):59-104.

Kruse, Fred A. 1988. "Use of airborne imaging spectrometer data to map minerals associated with hydrothermally altered rocks in the northern grapevine mountains, Nevada, and California." Review of. Remote Sensing of Environment 24 (1):31-51. doi: http://dx.doi.org/10.1016/00344257(88)90004-1.

Kurz, Tobias H., Julie Dewit, Simon J. Buckley, John B. Thurmond, David W. Hunt, and Rudy Swennen. 2012. "Hyperspectral image analysis of different carbonate lithologies (limestone, karst and hydrothermal dolomites): the Pozalagua Quarry case study (Cantabria, North-west Spain)." Review of. Sedimentology 59 (2):623-45. doi: 10.1111/j.1365-3091.2011.01269.x.

Kwarteng, Andy Y., Atsu S. Dorvlo, and Ganiga T. Vijaya Kumar. 2009. "Analysis of a 27-year rainfall data (1977-2003) in the Sultanate of Oman." Review of. International Journal of Climatology 29 (4):605-17. doi: 10.1002/joc.1727.

Lagacherie, Philippe, Frédéric Baret, Jean-Baptiste Feret, José Madeira Netto, and Jean Marc Robbez-Masson. 2008. "Estimation of soil clay and calcium carbonate using laboratory, field and airborne hyperspectral measurements." Review of. Remote Sensing of Environment 112 (3):82535. doi: http://dx.doi.org/10.1016/j.rse.2007.06.014.

Langmuir, Donald. 1996. Aqueous Environmental Geochemistry: Prentice Hall. Le Métour, J., D. Rabu, M. Tegyey, F. Béchennec, M. Beurrier, and M. Villey. 1990. "Subduction and obduction: two stages in the Eo-Alpine tectonometamorphic evolution of the Oman Mountains." Review of. Geological Society, London, Special Publications 49 (1):327-39. doi: 10.1144/gsl.sp.1992.049.01.20.

Lohmann, Kyger C. 1988. "Geochemical Patterns of Meteoric Diagenetic Systems and Their Application to Studies of Paleokarst." In Paleokarst, edited by Noel P. James and Philip W. Choquette, 58-80. New York, NY: Springer New York.

Nader, Fadi H., Rudy Swennen, and Eddy Keppens. 2008. "Calcitization/ dedolomitization of Jurassic dolostones (Lebanon): results from 
petrographic and sequential geochemical analyses." Review of. Sedimentology 55 (5):1467-85. doi: 10.1111/j.1365-3091.2008.00953.x. Sanz-Rubio, E., S. Sánchez-Moral, J. C. Cañaveras, J. P. Calvo, and J. M. Rouchy. 2001. "Calcitization of Mg-Ca carbonate and Ca sulphate deposits in a continental Tertiary basin (Calatayud Basin, NE Spain)." Review of. Sedimentary Geology 140 (1-2):123-42. doi: http://dx.doi.org/10.1016/S0037-0738(00)00175-5.

Searle, M., and J. Cox. 1999. "Tectonic setting, origin, and obduction of the Oman ophiolite." Review of. Geological Society of America Bulletin 111 (1):10422. doi: 10.1130/0016-7606(1999)111<0104:tsoaoo>2.3.co;2.

Siebert, Stefan, Maher Nagieb, and Andreas Buerkert. 2007. "Climate and irrigation water use of a mountain oasis in northern Oman." Review of. Agricultural Water Management 89 (1-2):1-14. doi: http://dx.doi.org/10.1016/i.agwat.2006.11.004.

van der Meer, Freek. 1995. "Spectral Reflectance of Carbonate Mineral Mixtures and Bidirectional Reflectance Theory: Quantitative Analysis techniques for Application in Remote Sensing." Review of. Remote sensing Reviews 13:67-94.

van der Meer, Freek D., Harald M. A. van der Werff, Frank J. A. van Ruitenbeek, Chris A. Hecker, Wim H. Bakker, Marleen F. Noomen, Mark van der Meijde, E. John M. Carranza, J. Boudewijn de Smeth, and Tsehaie Woldai. 2012. "Multi- and hyperspectral geologic remote sensing: A review." Review of. International Journal of Applied Earth Observation and Geoinformation 14 (1):112-28. doi: http://dx.doi.org/10.1016/j.jag.2011.08.002.

Vandeginste, Veerle, and Cédric M. John. 2012. "Influence of climate and dolomite composition on dedolomitization: insights from a multi-proxy study in the central Oman Mountains." Review of. Journal of Sedimentary Research 82 (3):177-95. doi: 10.2110/jsr.2012.19.

Vandeginste, Veerle, Cédric M. John, and Julia Beckert. 2015. "Diagenetic Geobodies: Fracture-Controlled Burial Dolomite in Outcrops From Northern Oman." Review of. Society of Petroleum Engineers (SPE) 18 (01):84-93. doi: 10.2118/173176-PA.

Vandeginste, Veerle, Cedric M. John, Tina van de Flierdt, and John W. Cosgrove. 2013. "Linking process, dimension, texture, and geochemistry in dolomite geobodies: A case study from Wadi Mistal (northern Oman)." Review of. Aapg Bulletin 97 (7):1181-207. doi: 10.1306/11011212076.

Windeler, D. S., and R. J. P. Lyon. 1991. "Discriminating dolomitization of marble in the Ludwig skarn near Yerington, Nevada using high-resolution airborne infrared imagery." Review of. Photogrammetric Engineering and Remote Sensing 57:1171-7.

Younis, M. T., M. A. Gilabert, J. Melia, and J. Bastida. 1997. "Weathering process effects on spectral reflectance of rocks in a semi-arid environment." Review of. International Journal of Remote Sensing 18 (16):3361-77. doi: $10.1080 / 014311697216928$.

Zeidan, Rashad H.. , and Muhammed H. Basyuni. 1998. "Modes of Occurrence of Dolomite in some Arabian Carbonate Rocks." Review of. Journal of King Abdulaziz University 10:1-16. 


\begin{tabular}{|c|c|c|c|c|c|c|c|c|c|c|c|c|c|}
\hline 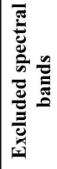 & 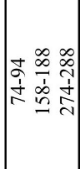 & 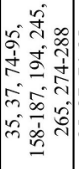 & 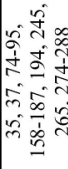 & 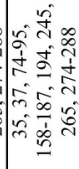 & 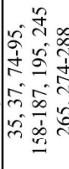 & 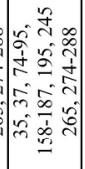 & 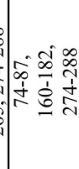 & 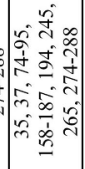 & 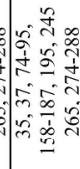 & 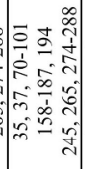 & 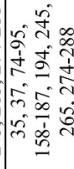 & 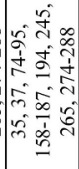 & 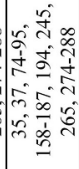 \\
\hline 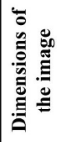 & 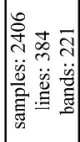 & 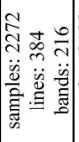 & 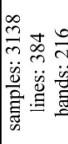 & 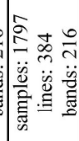 & 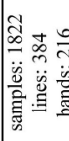 & 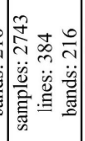 & 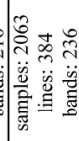 & 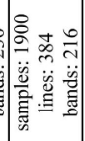 & 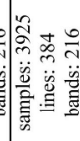 & 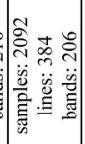 & 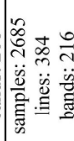 & 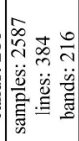 & 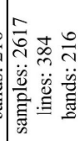 \\
\hline 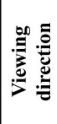 & $\underline{z}$ & $\omega$ & $\begin{array}{l}3 \\
\text { s. } \\
3\end{array}$ & 3 & 艺 & $\begin{array}{l}3 \\
2 \\
9 \\
3 \\
3\end{array}$ & 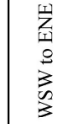 & 3 & 䓂 & $\frac{n}{z}$ & 3 & 文 & 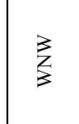 \\
\hline 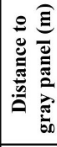 & i & $\stackrel{\circ}{\Omega}$ & $r$ & $m$ & + & i & $\cong$ & in & $\approx$ & $N$ & iి & $m$ & 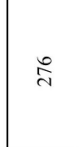 \\
\hline 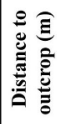 & $\stackrel{\Xi}{\Xi}$ & 导 & $\bar{F}$ & 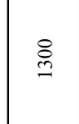 & $\underset{\infty}{\stackrel{P}{0}}$ & 号 & in & 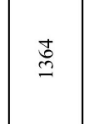 & ' & $\stackrel{n}{m}$ & స్లి & J & $\begin{array}{l}\text { S̃ } \\
\text { o } \\
\text { 告 }\end{array}$ \\
\hline$\stackrel{\text { g }}{E}$ & 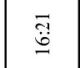 & ت્ֶ & $\underset{\dot{\alpha}}{\stackrel{p}{\alpha}}$ & $\stackrel{\vec{巳}}{ت}$ & 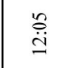 & $\begin{array}{l}\stackrel{\circ}{0} \\
\dot{\circ}\end{array}$ & $\stackrel{\mathscr{0}}{=}$ & $\stackrel{m}{\dot{I}}$ & $\begin{array}{l}\stackrel{\infty}{+} \\
\stackrel{\dot{g}}{g}\end{array}$ & 哭 & $\begin{array}{l}\mathscr{n} \\
\dot{o}\end{array}$ & $\stackrel{n}{\dot{d}}$ & 䡈 \\
\hline 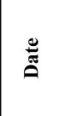 & 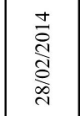 & 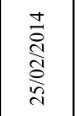 & 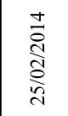 & 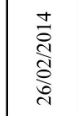 & 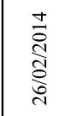 & 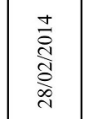 & 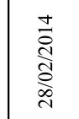 & 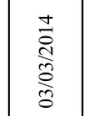 & 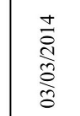 & 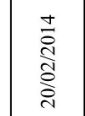 & 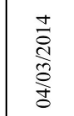 & 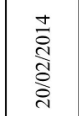 & 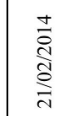 \\
\hline 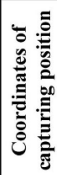 & 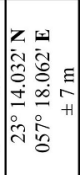 & 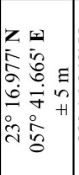 & 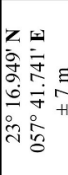 & 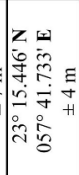 & 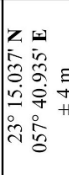 & 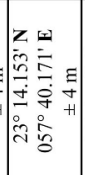 & 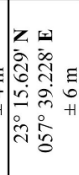 & 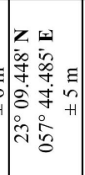 & 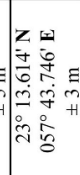 & 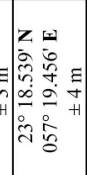 & 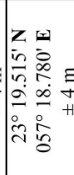 & 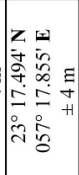 & 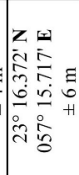 \\
\hline 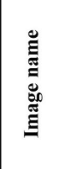 & $\begin{array}{l}0 \\
\vdots \\
0 \\
\vdots \\
1\end{array}$ & 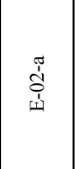 & $\begin{array}{l}\frac{\pi}{0} \\
\frac{1}{3} \\
\end{array}$ & \begin{tabular}{l}
$\frac{\pi}{3}$ \\
\multirow{3}{3}{} \\
3
\end{tabular} & $\begin{array}{l}\text { कू. } \\
\text { ô. } \\
\text { के }\end{array}$ & 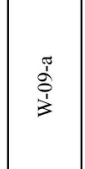 & $\frac{\pi}{\frac{\pi}{3}}$ & $\frac{0}{b}$ & 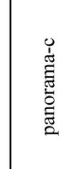 & 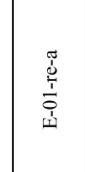 & $\begin{array}{l}\frac{\pi}{5} \\
\stackrel{5}{3}\end{array}$ & 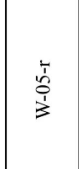 & 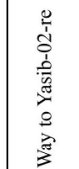 \\
\hline $\bar{z}$ & 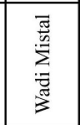 & 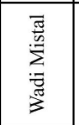 & 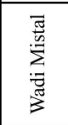 & 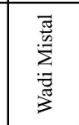 & 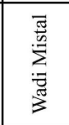 & 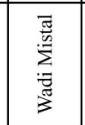 & 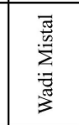 & 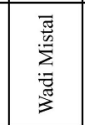 & 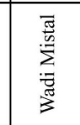 & 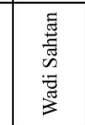 & 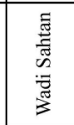 & 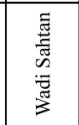 & $\begin{array}{l}\frac{0}{n} \\
\frac{\pi}{0} \\
0 \\
0 \\
0 \\
3 \\
3\end{array}$ \\
\hline
\end{tabular}

Table 1. Details of the ten hyperspectral images considered in this study such as the geographical position of the camera and the cliff face during image capturing. In addition the daytime and viewing direction is given as a well as eliminated bands in the spectra.

\section{$178 \times 270 \mathrm{~mm}(300 \times 300 \mathrm{DPI})$}


Table 2. Summary of Precambrian and Permian lithologies recognised in field observations. Massive and marly limestones as well as ED and DT2 dolomite were sampled in the outcrop in Wadi Mistal.

$$
149 \times 50 \mathrm{~mm}(300 \times 300 \mathrm{DPI})
$$




\begin{tabular}{|c|c|c|c|c|}
\hline Wadi & Image name & $\begin{array}{c}\text { Scale of the } \\
\text { hyperspectral } \\
\text { image }\end{array}$ & $\begin{array}{c}\text { Scale of } \\
\text { one pixel }\end{array}$ & $\begin{array}{c}\text { Height of the captured DT2 dolomite body } \\
\text { (position marked by white box in Fig. 11) }\end{array}$ \\
\hline Wadi Mistal & panorama-c & $1.0 \mathrm{~cm} \approx 185 \mathrm{~m}$ & $4.71 \mathrm{~m} \times 4.71 \mathrm{~m}$ & - \\
\hline Wadi Mistal & W-09-a & $1.0 \mathrm{~cm} \approx 89.9 \mathrm{~m}$ & $2.29 \mathrm{~m} \times 2.29 \mathrm{~m}$ & $25 \mathrm{~m}$ \\
\hline Wadi Mistal & W- $07-\mathrm{a}$ & $1.0 \mathrm{~cm} \approx 55 \mathrm{~m}$ & $1.40 \mathrm{~m} \times 1.40 \mathrm{~m}$ & $50 \mathrm{~m}$ \\
\hline Wadi Mistal & W-01-a & $1.0 \mathrm{~cm} \approx 17 \mathrm{~m}$ & $0.43 \mathrm{~m} \times 0.43 \mathrm{~m}$ & $35 \mathrm{~m}$ \\
\hline Wadi Mistal & W- $08-\mathrm{a}$ & $1.0 \mathrm{~cm} \approx 31 \mathrm{~m}$ & $0.79 \mathrm{~m} \times 0.79 \mathrm{~m}$ & $10 \mathrm{~m}$ \\
\hline
\end{tabular}

Table 3. Scale of the hyperspectral images and thickness of DT2 dolomite bodies.

$175 \times 44 \mathrm{~mm}(300 \times 300$ DPI $)$ 


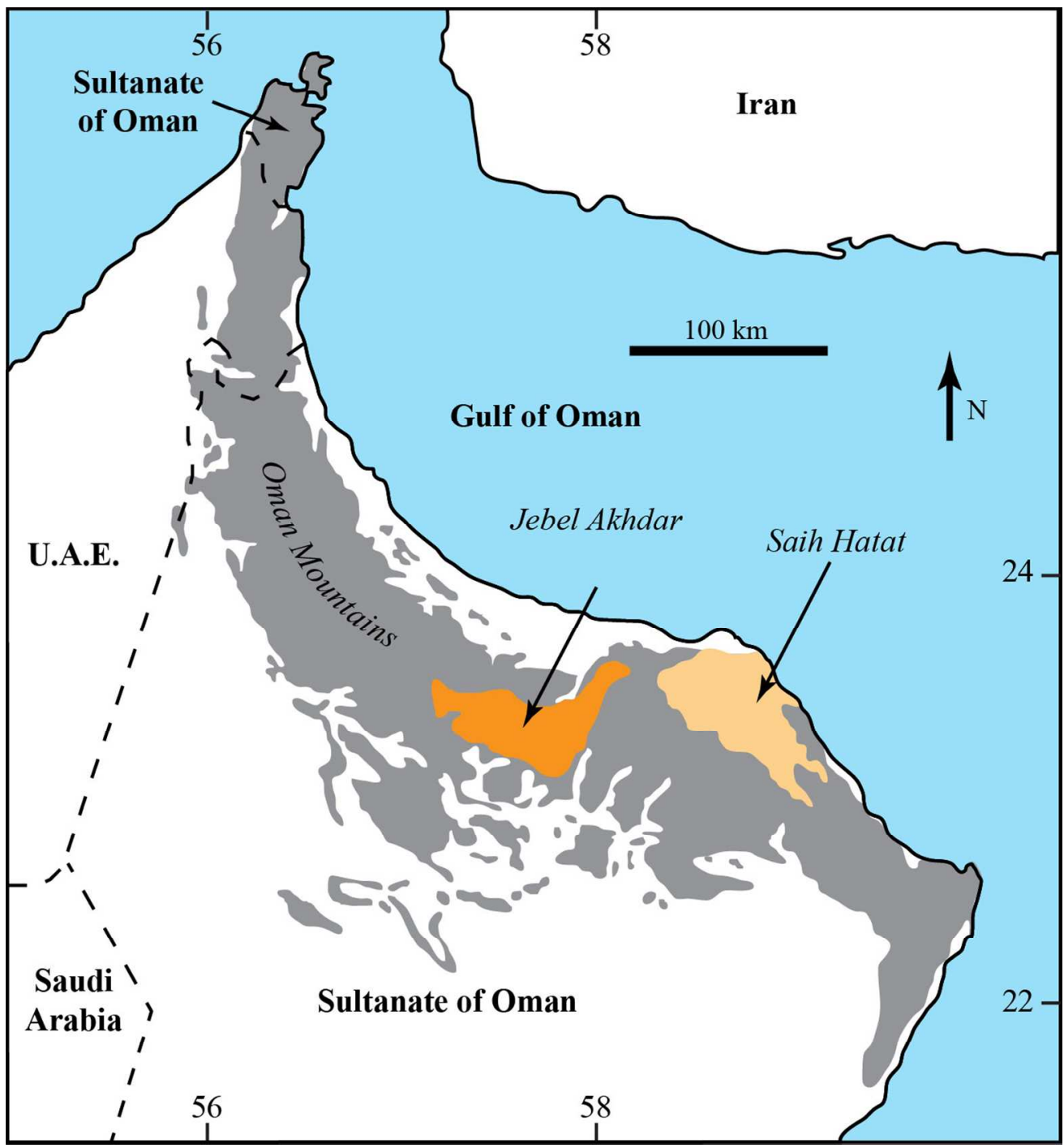

Fig. 1. Location of the Jebel Akhdar and the Saih Hatat in the Oman Mountains (map modified after Le Métour et al. (1990)).

$115 \times 124 \mathrm{~mm}(300 \times 300 \mathrm{DPI})$ 

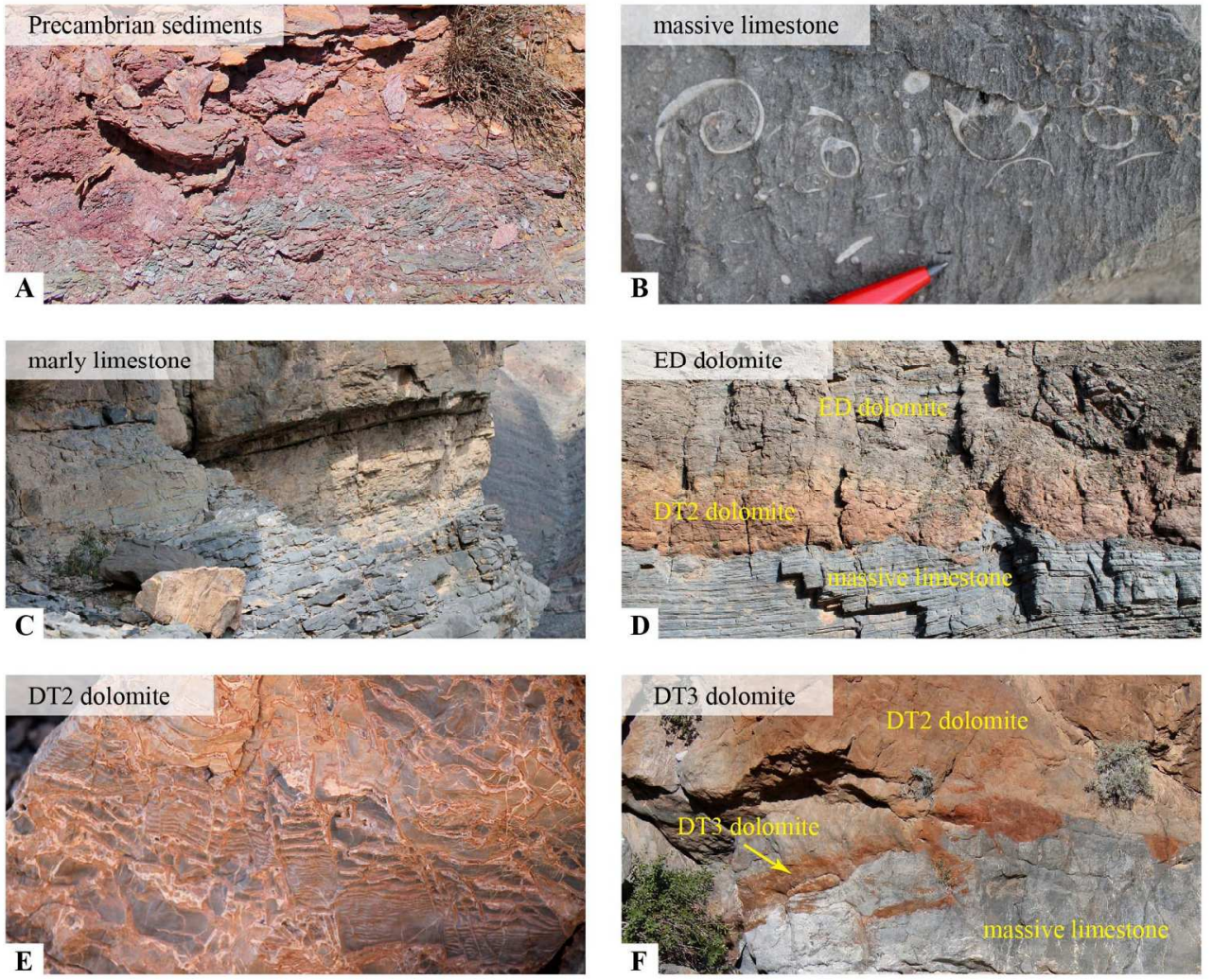

Fig. 2. Field photographs of the lithologies present in outcrops selected for hyperspectral imaging; most lithologies are also present at the Wadi Mistal outcrop.

$172 \times 139 \mathrm{~mm}(300 \times 300 \mathrm{DPI})$ 


\begin{tabular}{|c|c|c|c|c|c|c|c|}
\hline \multicolumn{8}{|c|}{ 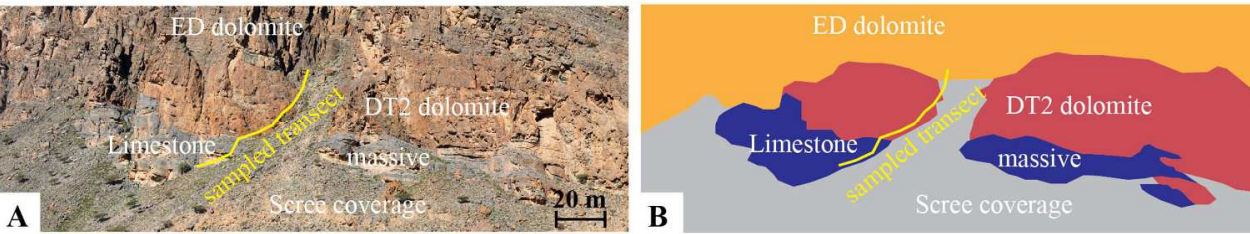 } \\
\hline \multirow[t]{2}{*}{ Lithology } & \multirow{2}{*}{$\begin{array}{c}\text { Field } \\
\text { samples }\end{array}$} & \multirow{2}{*}{$\begin{array}{c}\text { Stratigraphic } \\
\text { height (m) }\end{array}$} & \multicolumn{2}{|c|}{ ICP-AES measurements } & \multirow[b]{2}{*}{$\mathrm{Fe}(\mathrm{ppm})$} & \multirow[b]{2}{*}{$\mathrm{Mn}(\mathrm{ppm})$} & \multirow[b]{2}{*}{$\mathrm{Sr}(\mathrm{ppm})$} \\
\hline & & & $\mathrm{Ca}(\%)$ & $\mathrm{Mg}(\%)$ & & & \\
\hline ED dolomite & $W B A-35$ & 71.95 & 22.3 & 12.7 & 117 & 69 & 66 \\
\hline \multirow{21}{*}{ DT2 dolomite } & WBA-34B & 70.65 & 22.4 & 12.3 & 446 & 269 & 57 \\
\hline & WBA-34A & 69.05 & 21.8 & 12.2 & 303 & 228 & 49 \\
\hline & $W B A-33$ & 63.45 & 22.1 & 11.7 & 337 & 223 & 66 \\
\hline & WBA-31 & 59.25 & 22.1 & 12.3 & 1733 & 995 & 87 \\
\hline & WBA-28B & 54.45 & 22.5 & 11.9 & 4152 & 1767 & 88 \\
\hline & WBA-27 & 47.05 & 22.2 & 12.5 & 1883 & 946 & 83 \\
\hline & $W B A-26$ & 44.50 & 21.8 & 11.8 & 2170 & 712 & 88 \\
\hline & WBA-25 & 43.00 & 23.8 & 11.5 & 4966 & 2192 & 106 \\
\hline & WBA-22B & 34.55 & 22.4 & 11.6 & 7568 & 3219 & 76 \\
\hline & $W B A-21$ & 30.70 & 22.6 & 11.7 & 7819 & 3102 & 77 \\
\hline & WBA-20B & 29.05 & 22.1 & 11.5 & 7316 & 3376 & 75 \\
\hline & WBA-20A & 26.50 & 21.8 & 11.7 & 9008 & 3788 & 69 \\
\hline & WBA-19 & 24.60 & 22.3 & 11.4 & 5624 & 2884 & 82 \\
\hline & WBA-18 & 22.05 & 21.4 & 12.0 & 12392 & 4693 & 57 \\
\hline & WBA-17 & 21.35 & 22.8 & 11.5 & 7539 & 3794 & 95 \\
\hline & WBA-16 & 20.80 & 23.3 & 11.4 & 7922 & 4173 & 104 \\
\hline & WBA-15 & 19.80 & 23.2 & 11.7 & 1859 & 795 & 110 \\
\hline & $W B A-14$ & 19.50 & 21.5 & 11.8 & 5091 & 1746 & 78 \\
\hline & $W B A-13 B$ & 19.20 & 23.9 & 11.3 & 267 & 329 & 109 \\
\hline & WBA-13A & 19.15 & 24.2 & 12.1 & 219 & 311 & 143 \\
\hline & $W B A-12 A$ & 18.70 & 22.6 & 11.8 & 1047 & 1870 & 110 \\
\hline \multirow{12}{*}{$\begin{array}{l}\text { massive } \\
\text { limestone }\end{array}$} & WBA-11A & 18.70 & 38.4 & 0.9 & 126 & 140 & 196 \\
\hline & $W B A-10$ & 18.30 & 38.6 & 0.2 & 81 & 98 & 196 \\
\hline & $W B A-9$ & 17.30 & 39.0 & 0.3 & 134 & 30 & 269 \\
\hline & WBA-8 & 16.25 & 38.8 & 0.5 & 214 & 37 & 266 \\
\hline & WBA-7 & 15.10 & 39.4 & 0.2 & 319 & 33 & 296 \\
\hline & $W B A-6 B$ & 14.35 & 38.3 & 0.2 & 288 & 32 & 288 \\
\hline & WBA-6A & 14.35 & 39.4 & 0.2 & 292 & 31 & 295 \\
\hline & WBA-5 & 12.95 & 38.5 & 0.3 & 161 & 17 & 359 \\
\hline & $W B A-4$ & 8.15 & 38.1 & 0.4 & 102 & 14 & 424 \\
\hline & WBA-3 & 5.65 & 38.3 & 0.0 & 5 & 5 & 1414 \\
\hline & WBA-2 & 3.45 & 39.5 & 0.3 & 116 & 14 & 698 \\
\hline & WBA-1 & 0.00 & 38.0 & 0.1 & 105 & 15 & 617 \\
\hline
\end{tabular}

Fig. 3. (A) The mapped outcrop comprises most of the lithologies present in the hyperspectral images such as ED and DT2 dolomite and massive limestone. The sampled transect is shown as a yellow line. The hyperspectral image taken in this outcrop is defined as Wadi Mistal-W-01-a. (B) The sketch shows the digitized distribution of lithologies derived from the outcrop given in B. (C) In total 34 samples were taken along the transect covering massive limestone, DT2 dolomite and the base of ED dolomite. For later comparisons with spectra derived from the hyperspectral images 12 samples (displayed in bold italic) were selected. The table summarizes the results from the ICP-AES analysis focussed on the contents of calcium, magnesium, iron, manganese and strontium in the measured samples. Measurement uncertainties are $5 \%$ for calcium, magnesium and strontium and $3.5 \%$ for iron and manganese. In the following the results are rounded to the significant digit.

$177 \times 165 \mathrm{~mm}(300 \times 300$ DPI $)$ 

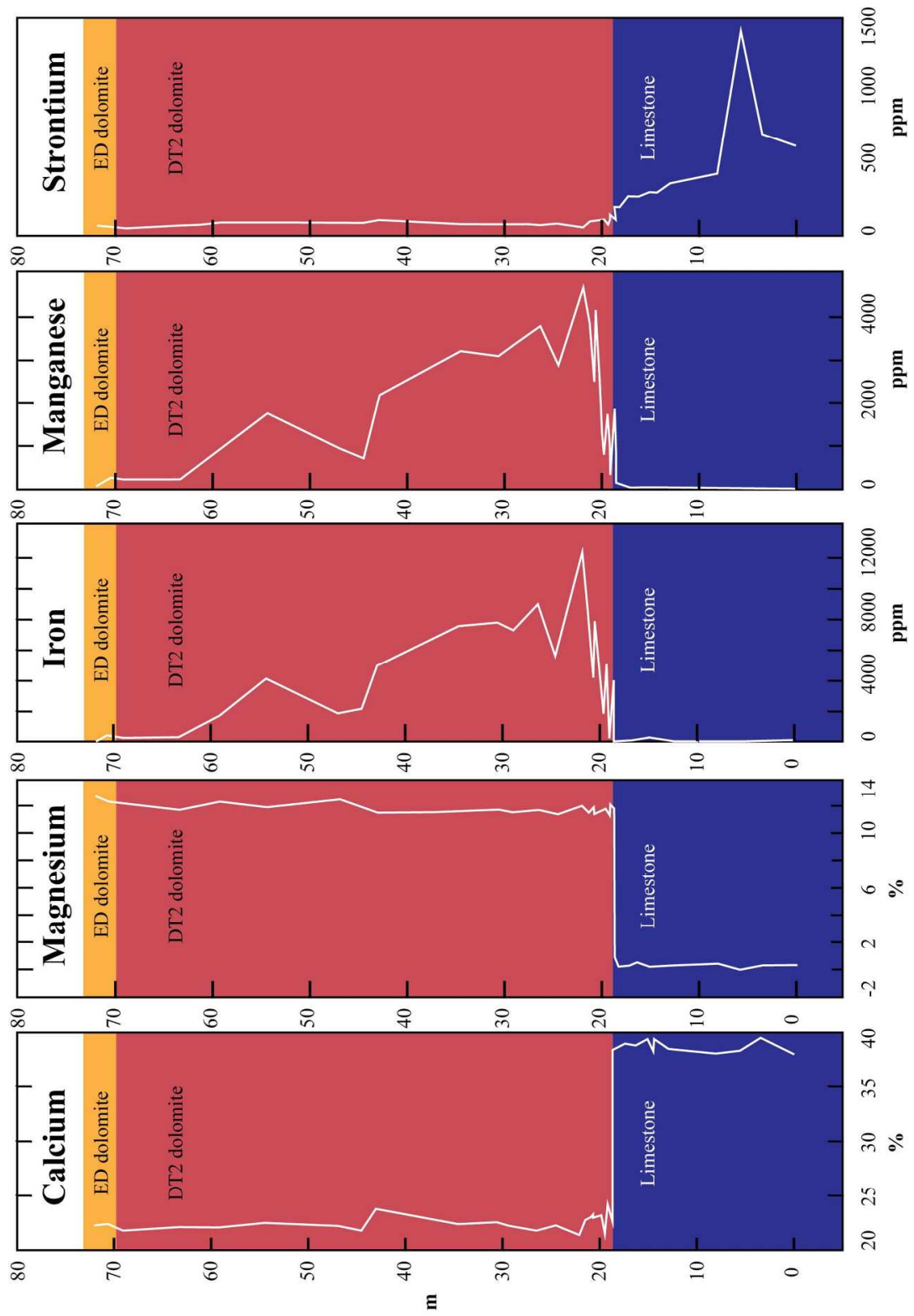

Fig. 4. Graphs of the geochemical variations of calcium, magnesium, iron, manganese and strontium measured with ICP-AES in function of distance along the transect through the stratigraphy. The colour scheme is similar to Fig. $3 \mathrm{C}$ and interpreted hyperspectral images.

$$
160 \times 228 \mathrm{~mm}(300 \times 300 \mathrm{DPI})
$$




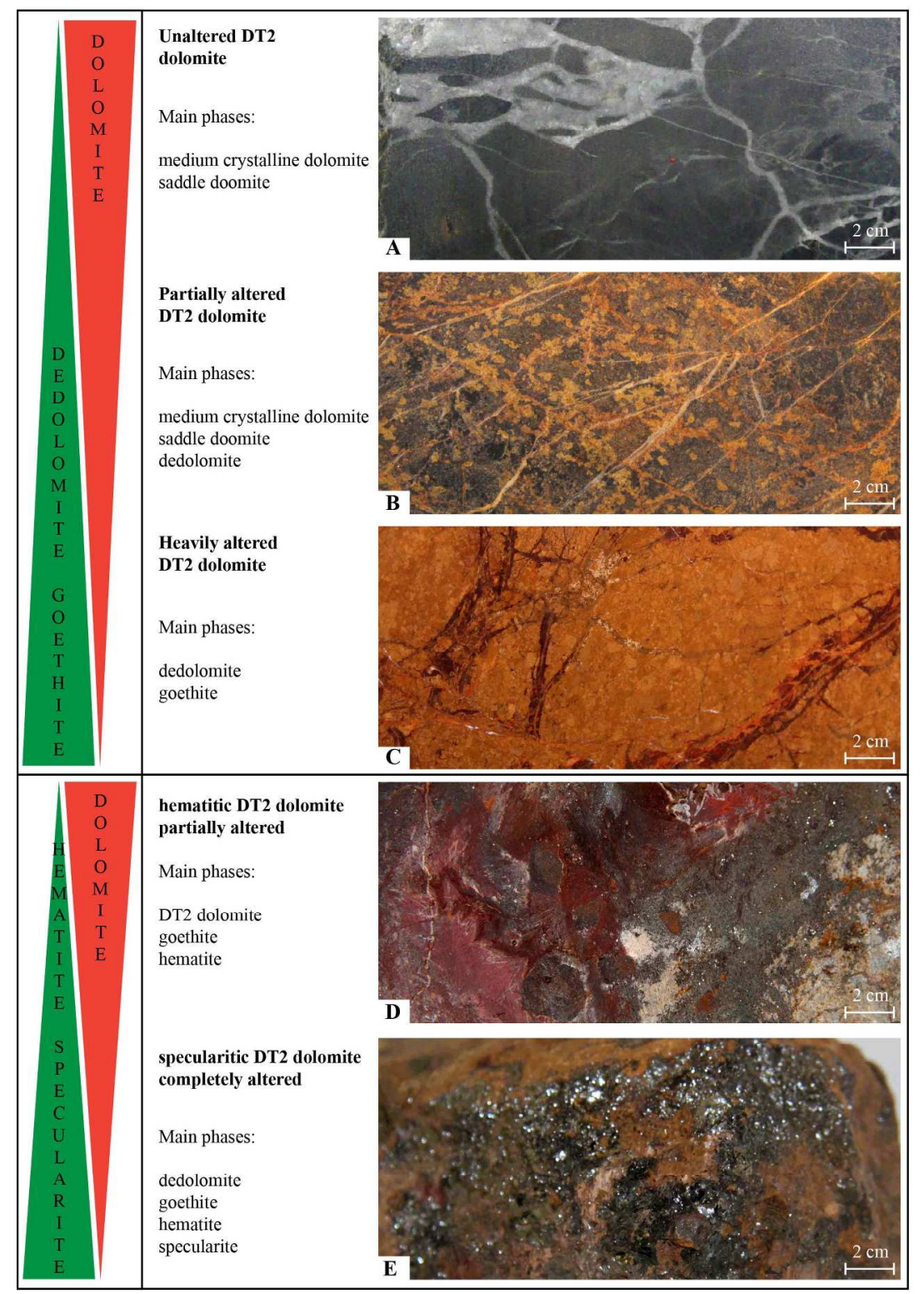

Fig. 5. (A) Photograph of fresh surface of a DT2 dolomite (grey areas) with saddle dolomite as a fractureand vein infilling (white areas). (B) Partially altered DT2 dolomites often show unweathered DT2 dolomite and dedolomite. Dedolomitization is mostly concentrated along veins and fractures. (C) Heavily altered DT2 dolomites lack unaltered areas and consist mainly of dedolomite and goethite. (D) In comparison to pictures $A, B$ and $C$, samples in pictures $D$ and $E$ are characterised by the intense precipitation of new non-dolomitic minerals. D shows a DT2 dolomite characterised by the precipitation of hematite and goethite whereas the DT2 dolomite itself lacks evidences for alteration. Only millimetre wide areas showing a brownish to orange colours contain dedolomite. (E) DT2 dolomites defined as specularitic DT2 dolomites consist mainly of specularite and hematite. Most of the DT2 dolomite is replaced by dedolomite.

$174 \times 250 \mathrm{~mm}(300 \times 300 \mathrm{DPI})$ 
Fig. 6. Carbon and oxygen isotope signature of unaltered DT2 dolomite (gray box - according to Beckert, Vandeginste, and John (2016)) in comparison with the two groups of altered DT2 dolomite. The dashed line marks the assumed trend with increasing intensity of alteration of group 1 and 2 respectively.

$$
104 \times 84 \mathrm{~mm}(300 \times 300 \text { DPI })
$$


Fig. 7. (A) Field panorama of the cliff face in Wadi Mistal presented in Fig. 3. (B) Interpreted hyperspectral image defined as Wadi Mistal-W-01-a. Five lithologies are present in this outcrop defined as massive limestone (blue), marly limestone (green), ED dolomite (yellow), DT2 dolomite (red) and DT3 dolomite (turquoise). The nomenclature of dolomite in this outcrop is consistent with those described in Vandeginste, John, and Beckert (2015) and Beckert, Vandeginste, and John (2015). For comparisons, the spectra of shales and sandstones of Precambrian age (derived from the hyperspectral image Wadi Mistal-E-06-C) are plotted as well.

$179 \times 168 \mathrm{~mm}(300 \times 300 \mathrm{DPI})$ 


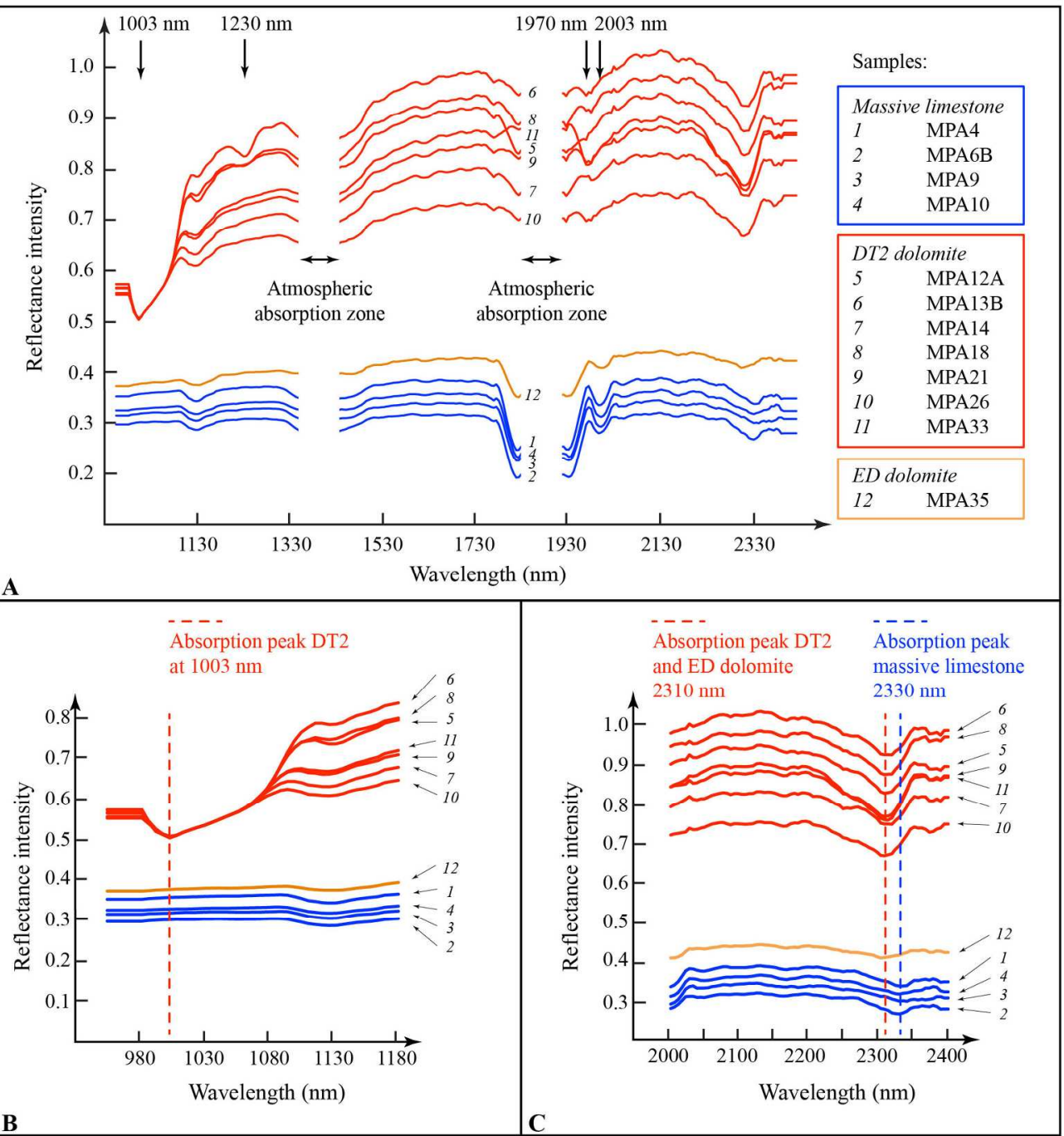

Fig. 8. (A) Graph of the spectra of massive limestones, DT2 dolomite and ED dolomite which were spectrally sampled at the same sampling locations as the geochemical samples (see transect in Fig. 3A and B). The colour scheme is similar to Fig. $3 \mathrm{C}$ and interpreted hyperspectral images. (B) One of the major differences in the spectra of DT2 dolomite and ED dolomite/ massive limestones is the presence of a strong absorption peak at $1003 \mathrm{~nm}$. (C) Limestone and dolomite spectra can be clearly distinguished by their characteristic absorption peaks at $2310 \mathrm{~nm}$ (DT2 and ED dolomite) and at $2330 \mathrm{~nm}$ (massive limestones).

$185 \times 197 \mathrm{~mm}(300 \times 300$ DPI $)$ 


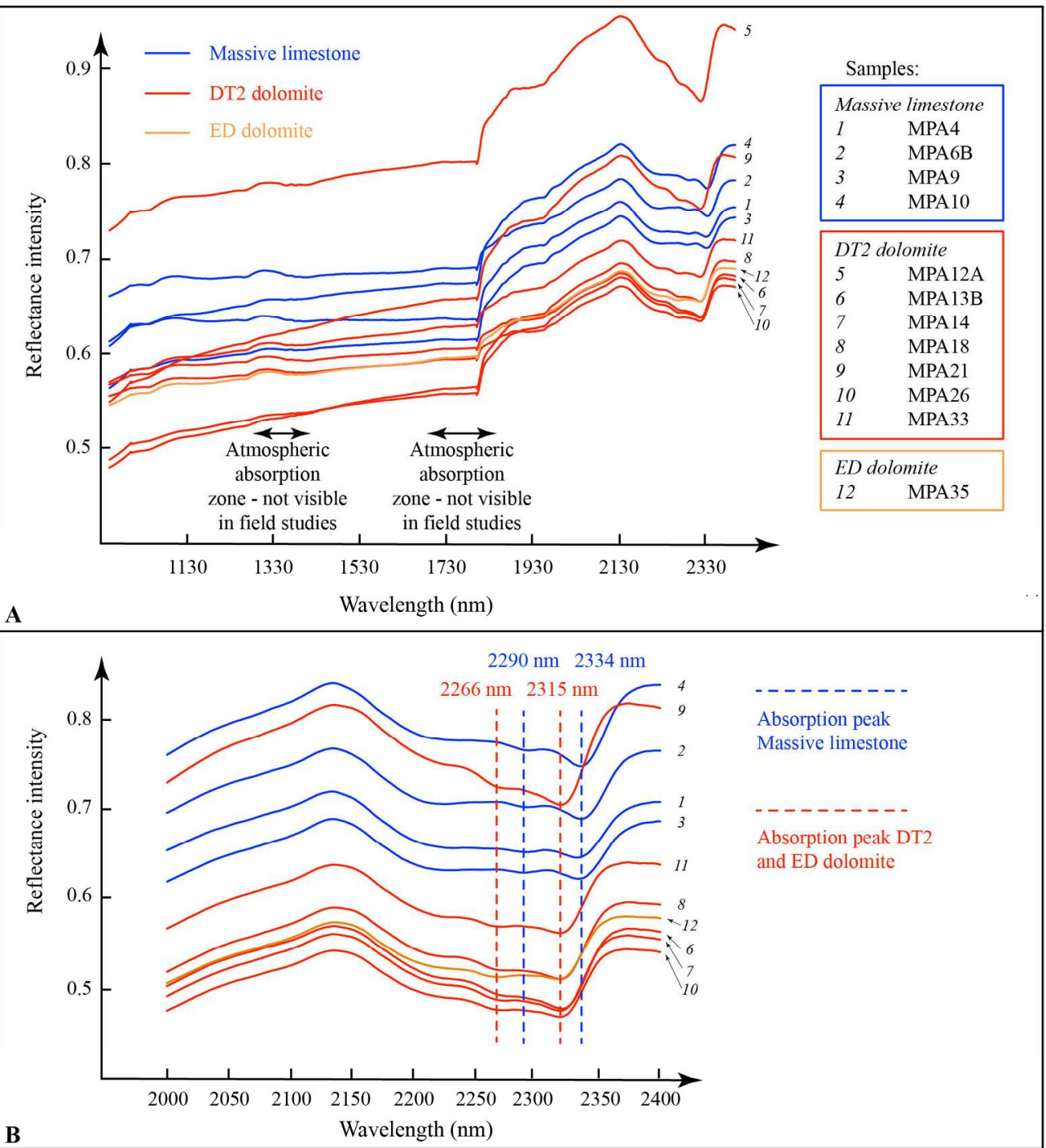

Fig. 9. (A) Spectra of powdered samples taken in one outcrop in Wadi Mistal (Fig. 3) which were spectrally measured under laboratory conditions. The position of atmospheric absorption zones is indicated for comparison with spectra collected in the field. (B) The graph displays the detailed positions of absorption peaks from $2000 \mathrm{~nm}$ to $2400 \mathrm{~nm}$. Limestones and dolomites reveal two significant absorption peaks at 2290 $\mathrm{nm} / 2334 \mathrm{~nm}$ and $2266 \mathrm{~nm} / 2315 \mathrm{~nm}$.

$185 \times 202 \mathrm{~mm}(300 \times 300 \mathrm{DPI})$ 


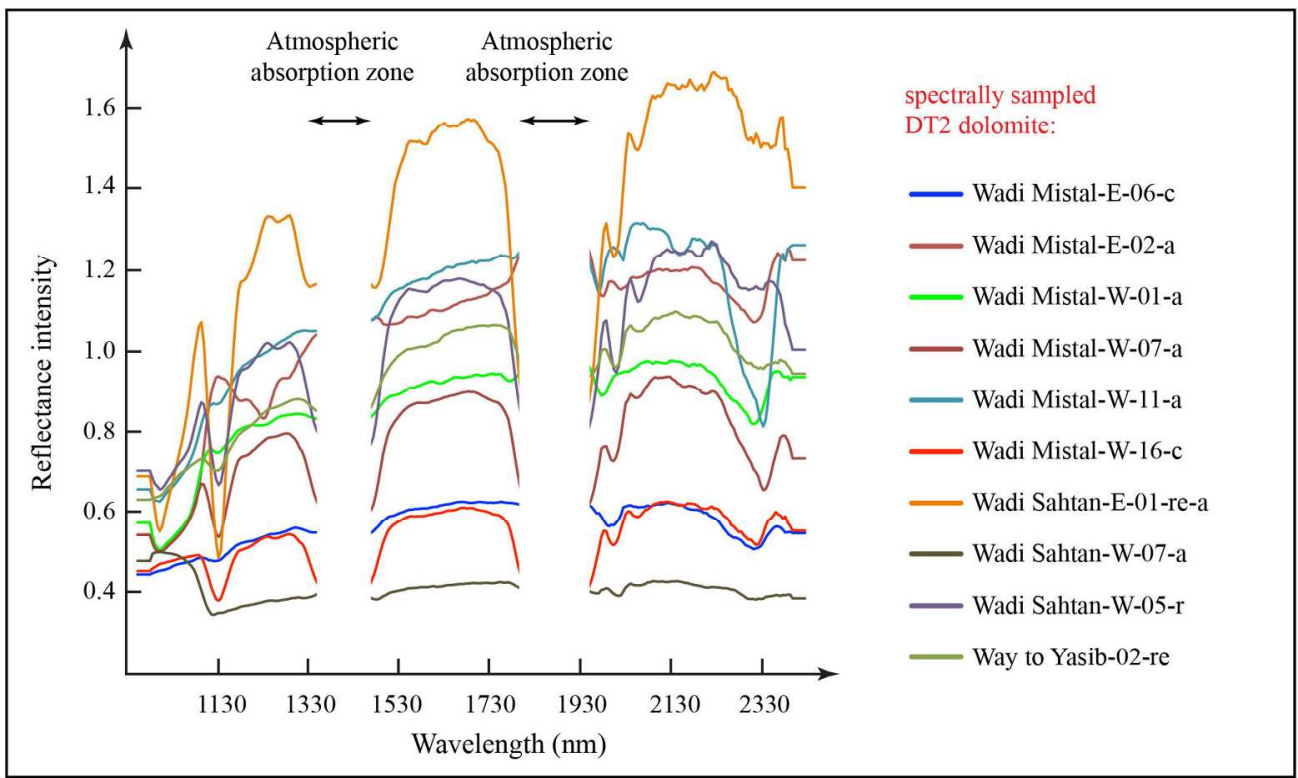

Fig. 10. Spectra derived from dolomite bodies which are distributed across the Central Oman Mountains.

$179 \times 108 \mathrm{~mm}(300 \times 300 \mathrm{DPI})$ 
Fig. 11. Overview of outcrop and interpreted hyperspectral images of the western area of Wadi Mistal. The lithologies detected on the interpreted hyperspectral images follow the key given in Fig. 8. An overview panorama is presented in (A) taken at a distance of $5 \mathrm{~km}$ to $9 \mathrm{~km}$ to the cliff faces (image scale $1: 18500$ ). Across the complete panorama only a few pixels indicate the presence of DT2 dolomite bodies. (B) (image scale 1:8990) and (C) (image scale 1:5500) were captured with a decreased distance of $1 \mathrm{~km}$ to $4 \mathrm{~km}$ to the cliff faces indicated as $B$ and $C$ in the overview panorama in A. At this distance DT2 dolomite bodies could be detected and a rough characterization of dolomite body shapes was enabled. At a distance of $50 \mathrm{~m}$ to $350 \mathrm{~m}$

((D) (image scale $1: 1700$ ) and (E) (image scale 1:3800)) details of the character of contact zones and smaller patches of DT2 dolomite could be detected.

$268 \times 187 \mathrm{~mm}(300 \times 300 \mathrm{DPI})$ 